NBER WORKING PAPER SERIES

\title{
INFLATION TARGETING AND JAPAN: \\ WHY HAS THE BANK OF JAPAN NOT ADOPTED INFLATION TARGETING?
}

\author{
Takatoshi Ito \\ Working Paper 10818 \\ http://www.nber.org/papers/w10818 \\ NATIONAL BUREAU OF ECONOMIC RESEARCH \\ 1050 Massachusetts Avenue \\ Cambridge, MA 02138 \\ September 2004
}

Paper to be presented at Conference on the Future of Inflation Targeting,Reserve Bank of Australia, August 9-10, 2004. The author is grateful for comments by Governor Ian MacFarlane, Robert McCauley, Frederic Mishkin, Warwick McKibbin, and other participants of the Conference. The views expressed herein are those of the author(s) and not necessarily those of the National Bureau of Economic Research.

C2004 by Takatoshi Ito. All rights reserved. Short sections of text, not to exceed two paragraphs, may be quoted without explicit permission provided that full credit, including (C) notice, is given to the source. 
Inflation Targeting and Japan: Why has the Bank of Japan not Adopted Inflation Targeting?

Takatoshi Ito

NBER Working Paper No. 10818

September 2004

JEL No. E42, E52, E58

\begin{abstract}
$\underline{\text { ABSTRACT }}$
The paper aims at explaining why the Bank of Japan has not adopted inflation targeting, despite calls for such a policy. Disclosed minutes of the Monetary Policy Meetings of the Bank of Japan, after March 1998, as well as Speeches by its members give clues to changing reasons against inflation targeting. Inflation targeting was not adopted in Japan in the early years (the first wave of interest in1999-2000) because the Board members were not sure about an appropriate price index, and a specific number for an appropriate inflation rate. A Bank of Japan study, completed in October 2000, did not give any clear answers. Inflation targeting was not adopted in later years (2001-2003), despite the inflation-targeting-like commitment strategy adopted in March 2001, because the Board members thought that conventional tools to increase the inflation rate were not available. As such, they thought that announcing a target with a positive inflation rate would damage confidence. In terms of introducing unconventional measures, the Bank of Japan worried about the transmission channels and the damage to its balance sheet. Towards the end of Governor Hayami $[$ fs term, the views against inflation targeting turned sharply negative, as news reports suggested that it may be linked to the new Governor 4 fs appointment. Therefore, , why inflation targeting was not adopted, can be explained and understood from a political economy perspective.
\end{abstract}

Takatoshi Ito

Graduate School of Economics

University of Tokyo

7-3-1 Hongo, Bunkyo-ku, Tokyo 113-0033

JAPAN

and NBER

itointokyo@aol.com 


\section{Introduction}

By any historical or cross-sectional standard, the Japanese economic slump from 1992 to 2004 (as of this writing) has been quite unusual. The economy that was once regarded as "number one" fell into a state of low growth, falling prices, and chronic banking crises for more than a decade. ${ }^{1}$ The average growth rate from 1993 to 2003 was just above 1 percent, in contrast to the average growth rate of 4 percent between 1975 and 1992. Slow growth was accompanied by disinflation in the first half of the 1990s, and, eventually, deflation since the mid-1990s. The stagnation in output and deflation in prices caused the Japanese economy to shrink - a rare phenomenon among advanced economies. From 1997 to 2002, Japanese nominal GDP (in yen) shrank by 4 per cent, while the nominal GDP of the United States (in US dollars) increased by 25 per cent.

Many factors have contributed to the stagnation of the Japanese economy since 1992. The long stagnation reflects the adverse combination of the negative wealth effects from the crash in asset prices, external shocks like the Asian currency crisis, and policy errors in bank supervision, fiscal policy, and monetary policy. In the early to mid-1990s, the burst bubble - a decline of stock prices by 50 to 60 per cent and the beginning of a long slide in real estate prices - meant that many corporations and households suffered from capital losses, and consumption and investment spending was curtailed. The most severely affected companies stopped interest and principal payments to banks. Non-performing loans became a serious policy problem by 1995 . Large fiscal stimulus packages were implemented in the mid-1990s, and the call interest rate was lowered to an unprecedentedly low level of 0.5 per cent in the fall of 1995. The stagnation of the Japanese economy from 1990 to 1995 can be largely explained by the extraordinary negative shocks to asset markets and the subsequent damage to the balance sheets of households and corporations.

After the mid-1990s, policy errors prevented the Japanese economy from returning to a firm recovery track. The two opportunities for recovery in 1996 and in 2000 were followed by negative growth and a (near) banking crisis. After a long stagnation, the Japanese economy began to recover in 1996, partly due to the large fiscal stimulus in 1995, and partly because of an increase in exports. As part of the 1995 "tax-reduction-now, tax-increase-later" package, an increase in the consumption tax in April 1997 had been planned. The expected increase in the consumption tax rate stimulated consumption in the second half of 1996 and the first quarter of 1997. It was difficult to see how much of the growth was due to a genuine recovery and how much was due to the intertemporal substitution of consumption. The planned tax rate increase was carried out, and consumption decreased as predicted in the second quarter of 1997.

The consumption tax rate increase and repeal of the income tax cut in April 1997 is often regarded as a mistake, in that fiscal tightening was applied to an economy in a nascent recovery. But, in evaluating the cause of sharp decline in the Japanese economic growth in 1998, it is difficult to separate the effects of the fiscal tightening of April 1997 from those of the Asian currency crisis, from July 1997 to the spring of 1998, and the banking crisis of 1997-98. The financial markets suddenly shrank due to the failures of one large bank and two securities companies (one large and one medium-sized) in November 1997. As a result of this incident, the government undertook a capital injection for the major banks in March 1998.

1 "Japan as Number One" was the title of a book written by Ezra Vogel (1979). A comprehensive description and analysis of the Japanese economy up to 1990 is available in Ito (1992). 
However, the additional capital proved insufficient, and two large banks failed in 1998. The second round of fiscal support in March 1999 put an end to the undercapitalization and fragility of Japanese banks, but only for a few years, as it later turned out. ${ }^{2}$

From 1995 to 2000, the US economy grew strongly without inflation; the "new economy" was believed to be supported by the widespread use of information and communication technology (ICT), as well as the growth in the ICT sector itself. This was not happening in Japan (or Europe), and one reason, I believe, is that regulatory barriers and the protection of jobs prevented the widespread use of ICT technology. Even without strong economic growth, ICT stock prices soared worldwide. The Japanese economy was partly helped by the stock price boom, and in 2000 the economy expanded by 3 per cent. However, the economy slumped again in 2001, and it went into another recession in 2002.

The extent of deflation increased from 2000 to 2003. The rate of CPI deflation reached around 1 per cent and the GDP deflator declined even more rapidly, at a rate of 3.5 per cent at one point. How to fight deflation became the top priority of monetary policy. Since many economists believe that inflation and deflation are ultimately monetary phenomenon, there was increased attention on the Bank of Japan.

The Bank of Japan Act was revised in 1997 after an intense debate in the public and in the parliament, and the new law became effective in April 1998. ${ }^{3}$ The legal and institutional independence of the Bank of Japan was enhanced: the Governor and Board members could not be dismissed for differences in opinions with the government, or any other reason other than physical and mental incapacitation. The newly enhanced Monetary Policy Board, consisting of the Governor, two Deputy Governors, and six fulltime members who must be recruited from outside the Bank, became fully responsible for setting monetary policy. Mr. Hayami, aged 72 and longretired from the Bank, was appointed as Governor. Some Board members from the old regime were retained, to be replaced at the expiration of their respective terms, and some vacancies were filled by new appointments with the new qualifications for Board members in mind. For example, Mr. Yamaguchi, a long-time Bank economist, and Mr. Fujiwara, a journalist, were appointed as Board members. Previously, the Board members represented different kinds of businesses - agriculture, large financial and regional financial institutions, and trade and industry - but under the new law, Board members had to have expertise in finance and banking. Two professors were also appointed as Board members: Professor Ueda of the University of Tokyo and Professor Shinotsuka of Ochanomizu University. ${ }^{4}$ Minutes of discussions (without names) and voting records (with names) were to be disclosed with a delay of about one month, as a part of enhanced transparency. The mandate of the new Bank of Japan was clearly price stability, while the mandate of the Bank under the old law was to help maximize the potential growth of the economy. ${ }^{5}$

2 For the failure of bank supervision and crisis management in the 1990s, see Cargill, Hutchison and Ito (1997, 2002). Ito and Harada (2000) showed that the Japanese premium, the spread charged by the western banks on interbank lending rate to Japanese banks, virtually disappeared after April 1999.

3 See Cargill, Hutchison, and Ito (2000) for comparison of the legal language of the old and new Bank of Japan law, the change in the independence index, and an assessment of experiences of the Bank operations during the early years.

4 These professors had to resign from their respective universities, as the Board member position required full time employment at the Bank of Japan.

5 The word "potential" was probably meant to be the war power as the old law was enacted in 1942. 
With independence, the Bank of Japan became accountable to the public for its actions and their consequences. Deflation, many critics argued, was the proof of its failure. As deflation became worse, critics argued that there was a danger of a deflationary cycle: deflation generates deflationary expectations, which raises the real interest rate and depresses investment and consumption; and lower aggregate demand results in more deflation. The Bank should have done everything it could to prevent deflation from worsening. The Bank - both Board members and staff economists initially argued that deflation was not so serious and, moreover, deflation that resulted from technological innovation and cheaper imports could be desirable. The Bank lowered the policy interest rate (the call rate) to virtually zero in February 1999. As the nominal interest rate cannot become negative, the zero interest rate policy was the ultimate conventional monetary policy instrument available to the Bank. However, from mid-1999 to 2000, calls for additional action to fight deflation increased among policy makers and academics. The list of additional or unconventional (from the perspective of standard textbook central banking) policies included quantitative easing (expanding the monetary base); an increase in the purchase of long-term government bonds; the purchase of riskier assets including commercial paper, corporate bonds, equities, and foreign bonds; and, the adoption of inflation targeting. The arguments raised by proponents of inflation targeting included greater accountability, instrument independence, better communication with the market, and an influence on inflation expectations to break the deflationary cycle.

In fact, inflation targeting became somewhat symbolic of the additional unconventional steps that many argued the Bank of Japan should take to achieve a positive inflation rate. Most of the Bank's Board members and staff economists were publicly dismissive of inflation targeting. Several reasons were mentioned. First, inflation targeting was a simple-minded reflation policy. Second, no country had adopted inflation targeting to move from deflation to inflation. Third, there were no available policy measures to lift the inflation rate to positive territory, given that the interest rate was zero, so the announcement of inflation targeting, without tools to achieve a positive inflation rate, would damage the Bank's credibility. Fourth, the mere announcement of an inflation target would not change expectations. Fifth, if the public believes in the inflation target, the long-term interest rate would increase and this would damage the economy.

The Bank not only rejected calls for additional ways of easing monetary policy but tightened monetary policy, by 0.25 percentage points, in August 2000, citing a brighter outlook of the economy. However, the inflation rate was still in negative territory. This turned out to be a costly mistake: the ICT stock bubble had already burst and the US economic outlook was deteriorating; the peak of the cycle was near in Japan too. Sure enough, the economy started to contract from October 2000. The economy deteriorated to such an extent that the Bank of Japan had to change course in March 2001, and return to the zero interest rate policy. At the same time, the policy instrument was changed to the current account at the Bank of Japan (basically excess reserves at the Bank of Japan). By targeting excess reserves, a regime of quantitative easing had started. In March 2001, the target for current account balances was set at 5 trillion yen, at the time when required reserves was about 4 trillion yen. The target amount has since been raised in several steps, and reached the range of 30-35 trillion yen in January 2004. The Bank also expanded its purchase of long-term bonds. The amount of monthly purchases was raised from 400 billion yen to 600 billion yen in August 2001, and in several steps to 1,200 billion yen in October 2002. Thus, since 
March 2001, the Bank has adopted some unconventional policy measures, but not inflation targeting.

The term of Governor Hayami expired in March 2003. He was replaced by $\mathrm{Mr}$ Fukui, employed in the private sector for the five years prior to his appointment, but an earlier Deputy Governor of the Bank of Japan. The tone of statements and communication with the public became much better than under Governor Hayami. Under Governor Fukui, the confrontational style with the government has melted away, and the fixation on raising interest rates as soon as possible has also disappeared. However, Governor Fukui has not adopted inflation targeting. The economy started to recover in the second half of 2003 and the growth rate has climbed up to above 3 per cent in 2003, and is expected to remain around this level in 2004. The degree of deflation has shrunk to near zero, and economic expansion is spreading from the electronic machinery and export sectors to consumption.

As the economy continues to expand, some observers have started to speculate about when the zero interest rate policy will be lifted. In October 2003, the Board refined the necessary conditions for lifting the zero interest rate policy: the CPI inflation rate (excluding fresh food) has to be zero or above, on average, in the past few months; and the inflation rate has to be projected to stay above zero in the near future. Many private-sector forecasters predict that if the economic growth continues to accelerate in the second half of 2004 and the first half of 2005, the necessary conditions to end the zero interest rate policy will be achieved sometime in 2005 . There is a growing call for adopting the inflation targeting as a part of the exit strategy from the zero interest rate regime.

The rest of this paper is organized as follows. Section 2 reviews experiences of deflation and monetary policy actions from 1998 to 2004. Section 3 examines the pros and cons of inflation targeting. Why the Bank of Japan did not adopt inflation targeting will also be explained. Section 4 concludes the paper.

\section{Deflation and Monetary Policy}

\subsection{Deflation: Measurement and Effects}

Measured by the CPI (excluding fresh food), Japan has experienced deflation for much of the period since July 1998 and measured by the GDP deflator, Japan has been in deflation for nearly all of the period since the third quarter of 1994 . $^{6}$ The level of the CPI in 2003:4 is 2.5 per cent lower than in 1998:4, and the GDP deflator in 2003:4 is 10.8 per cent lower than that in 1993:4. This is deflation.

The changes in the CPI and GDP deflator are shown in Figure 1. Prior to 1995, the series moved in parallel most of the time, but have since deviated. The CPI, calculated using the Laspayres index formula, has an upward bias, while the GDP deflator, calculated using the Paasche index formula, has a downward bias. Quality changes that are not fully captured in price measurement, in either the CPI or GDP deflator, would create an upward bias. ${ }^{7}$ That explains part of the deviation. However, the reason for the widening of the bias is not immediately clear. It is also puzzling that even the directions of changes from 1998 to 2003 are different. For example, from

6 Since 1994:1 to the present (2004:1), the change in the GDP deflator was continuously negative, except for the period from 1997:2 to 1998:1. This period was possibly influenced by the increase in the VAT rate from 3 per cent to 5 per cent. Theoretically, the GDP deflator should not be affected by the VAT, but the numbers are suspiciously higher for one year. An adjustment for the VAT tax increase is made in the following analysis.

7 Shiratsuka (1999) estimated the bias in the Japanese CPI to be 0.9 per cent. 
2000 to 2002, CPI deflation worsened, while GDP deflation moderated; and from 2002 to 2003, CPI deflation disappeared, while GDP deflation worsened. At the time of this writing the CPI is showing about zero inflation, while the GDP deflator is indicating 2 to 3 per cent deflation.

Whether this magnitude of deflation is a serious problem is debatable; Bank of Japan economists tend to take the optimistic view. Moreover, in 1999 and 2000 many Board members, including Governor Hayami, strongly argued that a decline in prices due to technological innovation, such as in computers, and cheap imports, is "good deflation" and is not a concern for policy-makers. ${ }^{8}$ However, as the duration of the deflation increases, the decline in prices becomes large, and this has an impact on the real side of the economy. The impact of technological advancement and cheap imports on the price level raises the question of whether deflation occurred due to supply side factors (that is, the aggregate supply curve shifted right) or to demand side factors (that is, the aggregate demand curve shifted left). ${ }^{9}$

Since technological innovation and cheap imports from China are a global phenomenon, and not just a Japan-specific phenomenon, it would be incorrect to think that this is a major reason for the Japanese deflation. In the case of the US, where the "new economy" (high growth, low unemployment and stable prices) was observed, it could be argued that the supply side effects, namely productivity increases, made possible an output expansion without accelerating inflation.

It should also be noted that computers and other ICT-related produces and services, and imports from China, are only a small fraction of consumer prices. The gross import to GDP ratio is around 10 per cent in Japan, and the Chinese share in imports is about 20 per cent. So, the direct impact of China on the GDP should be about 2 per cent. Even if the import prices from China dropped by a large margin, the direct impact would be limited. However, those who emphasize the impact from China argue that indirect effects on Japanese made products are important. Many Japanese goods, including food, CDs, electronics, and even machinery, have become "contestable", due to potential supply from China. The direct share of imports is thus argued to underestimate the impact of globalization on the Japanese prices.

Relative prices are certainly affected by innovation and globalization, but it does not follow that the general price level, such as that measured by the CPI, should follow the trend of a small category of goods and services. We expect that general price inflation is a monetary phenomenon, rather than the accumulation of relative prices changes.

8 "Though it is true that prices of a number of products have been declining, this is against the backdrop of various revolutionary changes including the so-called IT revolution, that is, the progress of technological innovation in information and telecommunications, as well as the revolution in distribution networks represented by the emergence of so-called 'category killers'. Such phenomena cannot necessarily be regarded as pernicious price declines" (speech by Masaru Hayami, Governor of the Bank of Japan, to the Research Institute of Japan in Tokyo on March 21, 2000).

9 Hayashi and Prescott (2002) argued that the economic stagnation of Japan in the 1990s was largely due to the slowdown in productivity growth, resulting from a reduction in the work week and other supply-side factors, such as capital deepening, which resulted in low returns to capital. The basic methodology assumes that actual GDP was tracing potential GDP most of the time, a tradition of real business cycle theory. This view sharply contrasts with the dominant view that aggregate demand growth was far less than potential, although estimates of the GDP gap vary from one researcher to another. See McKibbin (2001) for a simulation analysis of the Japanese economy, where inflation targeting was shown to be beneficial to the Japanese economy. 


\subsection{Cost of Deflation}

In the case of Japan, unlike the US, disinflation and eventual deflation were the result of recession (a shift in the aggregate demand curve) rather than output expansion (a shift of the aggregate supply curve). In order to see the relationships between inflation and growth, and between inflation and unemployment, Phillips curve figures can be used. Figure 2 shows the relationship between the rate of CPI inflation and GDP growth (both measured as the four-quarter ended percentage change). The figure shows a non-linear, although generally positive, relationship between the two variables: namely, lower inflation is associated with lower growth, suggesting that demand shocks are more dominant than supply shocks. However, the relationship is less robust if the sample is limited to the stagnation period (19932004).

Figure 3 shows the traditional Phillips curve relationship between the inflation rate and the unemployment rate. It used to be the case in Japan, say in the 1950s and 1960s, that the Phillips curve was more or less vertical (that is, there was little variation in the unemployment rate). This is no longer true. A typical downward sloping curve, with a strong nonlinearity around 2 per cent inflation, can now be observed. The kink at around 2 per cent seems consistent with the predictions of Akerlof, Dickens and Perry (1996). Although the long-run Phillips curve is more or less vertical above the 2 per cent level of inflation, it is strongly downward sloping below the 2 per cent level. Akerlof, Dickens and Perry attribute such a result to the downward rigidity of nominal wages, providing evidence in support of this proposition. At a very low inflation rate, the adjustment of relative wages between different sectors becomes difficult thereby increasing unemployment.

However, the extent of wage rigidity is smaller in Japan, because a substantial part (typically from 2 to 5 months equivalent) of annual earnings are paid in the form of bonuses for regular workers (not only executives, but also rank and file employees), and bonuses respond quite flexibly to company performance. Kuroda and Yamamoto (2003a, b), using Japanese longitudinal data from 1993 to 1998, argued that the impact of wage rigidity on unemployment is quite small in Japan, at least among regular workers. Although downward nominal wage rigidity does exist in Japan, it is most prevalent among hourly-wage, part-time female employees, and is of limited importance for the regular monthly salaries and annual earnings of full-time employees. ${ }^{10}$ Kuroda and Yamamoto (2003c) simulated the impact of downward rigidity on the male unemployment rate. Using the estimated rigidity for the full-time male workers (which is smaller than for other type of workers) from their previous studies, they fit the data to the Akerlof, Dickens and Perry model. The simulation showed that downward rigidity would raise the unemployment rate by as much as 1.8 percentage points under the baseline parameters. Downward wage rigidity does not cause unemployment as long as the inflation rate is approximately 2.4 per cent or higher, whereas rigidity effects tend to increase gradually as the inflation rate falls

10 Kuroda and Yamamoto (2003a, b) established the existence of downward rigidity of wages, and quantified the extent of this downward rigidity by applying econometric methods to control for the individual characteristics and the measurement errors. They argued that the rigidity in regular monthly salaries of full-time male and female employees were subject to a threshold: the monthly salary will not be cut as long as the notional (desirable from the employers' point of view) wages do not decline by more than about 7.7 percent and 4.0 percent, respectively. However, when the notional wage change rates exceed these threshold values, nominal wage cuts do occur. 
below 2.4 percent. This is consistent with Akerlof, Dickens, and Perry (1996). One of Kuroda and Yamamoto's more interesting conclusions is that when inflation is below approximately 1 per cent, the marginal increase in unemployment attributable to downward rigidity becomes small, since bonus adjustments and extensive wage cuts would be triggered at that point. However, the unemployment rate rose to 5.3 per cent in 2003, which was five years after their data set stopped. It would be interesting to see whether the same conclusion holds at the right-end tail of the Phillips curve.

Taking Kuroda and Yamamoto (2000a, b, c) literally, the cost of deflation was not evident through the wage rigidity channel in Japan. ${ }^{11}$ Another channel from deflation to output and employment is through corporate activities that suffer from unexpected disinflation and deflation. In general, unexpected disinflation leads to income redistribution from borrowers to lenders. ${ }^{12}$ Borrowers that borrowed longterm funds at high interest rates suffer from low profits, and would not raise wages. Lower wages depress consumption and therefore output.

The number of corporate bankruptcies in Japan rose from about 6,500 in 1990 to about 19,000 in 2001, an almost three-fold increase. Not only did small and medium size firms go bankrupt, but large corporations also started to fall victim of stagnation toward the end of the 1990s. The total amount of bankrupt companies' debt increased form 2 trillion yen in 1990 to 26 trillion yen in 2000, a 13-fold increase. While unexpected disinflation is not the sole cause of bankruptcies, the combined impact of weak economic activity and disinflation does explain a major part of the dramatic increase in corporate bankruptcies. When many corporations go bankrupt, unemployment will increase, which is likely to be sustained for some time.

What makes the Japanese case more complex is that asset prices have fallen much faster than the general price level. Asset price deflation hit the construction and real estate sectors hard. The non-performing loans common in these sectors by the mid-1990s, dragged some financial institutions into insolvency. Deteriorating collateral values made recovery of loans more difficult. As the balance sheets of banks started to deteriorate quickly in the mid-1990s, the economic problem spread through the financial system. Large and medium-sized financial institutions failed in 1997-98 and again in 2003. The protracted systemic instability also damaged potential growth. The general deflation and asset price deflation were obviously intertwined and reinforced each other. ${ }^{13}$

If asset values fall below the nominal amount of debt, those who borrowed and invested in assets (such as real estates, equities, paintings, etc.) will find it difficult to

11 The literature that questions the Akerlof, Dickens, and Perry mechanism includes Lebow, Stockton, and Wascher (1995), Card and Hyslop (1997), Lebow, Saks and Wilson (1999), Crawford and Harrison (2000), Fares and Lemieux (2000), and Groshen and Schweitzer (1996, 1999).

12 Corporations that borrowed long-term funds expecting that their product prices would rise at a constant positive rate, and planned nominally-contracted repayment to banks based on the growth in nominal revenues, would suffer from an increasing real burden of repayments if an increase in product prices falls short of expectation. For example, think of a firm that contracted a 10-year loan in 1990 at a 6 percent interest rate, hoping that the prices would continue to rise at 3 percent for the following ten years. Prices rose only 10 percent from 1990 to 2000, instead of 30 percent. If product prices behave similarly, revenues are lower than expected by 20 percent by the end of borrowing period. However, the amount of interest and principal payment to the bank would not change. Corporations may go bankrupt if the revenue shortfalls becomes serious or if interest payments cannot be made. Deflation is definitely bad for borrowers.

13 Cargill, Hutchison, and Ito $(1997,2000)$ and Hoshi and Kashyap (2001) discuss the structural problems in the corporate-bank relationship and bank and corporate governance in Japan. 
repay debts. Unexpected disinflation or deflation is a mechanism for unintended transfers of wealth from borrowers to lenders. This is quite harmful to the macroeconomy - just like unexpected inflation - and also to the functioning of capital markets. If investors are unable to sell their property, payments to banks would cease, creating non-performing loans. The fall in asset prices also discourages investment in assets, until new buyers are convinced of a bottoming out in the market; in the process, prices will fall further. The banks with nonperforming loans will become reluctant to extend any kind of bank loans and a credit crunch would result. The debt problem arising from asset price deflation and nominal debt contracts is known in the literature as debt deflation, especially in the context of the Great Depression. ${ }^{14}$

In addition to the costs of lost output, deflation may have other negative consequences for the economy. Deflation now may cause people to expect further deflation in the future. With expectations of deflation, if interest rates have already reached zero, monetary policy loses its potency, because the nominal interest rate is bound at zero. With a zero nominal interest rate, the real interest rate increases as the expected inflation rate becomes lower. A high real interest rate in a stagnant economy reduces corporations' incentives to invest to expand production. In a sense, companies burned once by unexpected disinflation will not invest, say in additional plant and machinery, until the inflation rate is stabilized at a positive level. Deflation will therefore cause more deflation by generating deflationary expectations. This is the mechanism of a deflationary spiral.

Although Bank of Japan economists tended to argue that deflation was mild, and a deflationary spiral never happened, there is some evidence that deflation and deflationary expectations deteriorated from 1999 to 2002. The Bank of Japan Monetary Policy Board has published a semi-annual Outlook since October 2000. In the Outlook, Board members express their expected inflation rate for the fiscal year (where fiscal year $t$ runs from April of year $t$ to March of year $t+1$ ). In October 2000, the Board members' inflation expectation, taking out the most optimistic and most pessimistic forecasts, for FY 2000 (note that the time of poll was already in the middle of the FY) ranged from -0.4 to -0.2. The expectation of FY 2001, at the beginning of that FY (April 2001) ranged from -0.8 to -0.4. One year later, at the time of April 2002 in FY 2002, the expectation was for further deflation, ranging from -1.0 to -0.8 . It would therefore seem that deflationary expectations increased from 2000 to 2002.

In Japan, one additional consideration is the impact of deflation on fiscal settings. One of the largest borrowers at fixed interest rates is the Japanese government, with outstanding long-term debts of 550 trillion yen, more than 100 per cent of GDP. The Japanese government has regularly issued long-term government bonds with fixed interest rates. (Only in 2003, did the Japanese government start to issue inflation-indexed bonds, where the principal is protected from deflation.)

Unexpected deflation during the 1990s meant that the Japanese government had an increased real debt burden - that is, more taxes in real terms have to be collected than otherwise to repay debt. In addition, since tax brackets are not adjusted for inflation, deflation meant that the government had less tax revenues due to the reverse of the well-known bracket creep phenomenon.

14 Irving Fisher (1933) was the first to note the debt deflation process. The Great Depression is often used as an example of very negative consequences of debt deflation. See Bernanke (1983) and Mishkin (1978, 1991, 1997), and Mishkin (1998) for application to Japan. 


\subsection{Policy Responses in Chronology}

As the economic slump continued, the Bank of Japan has changed its position on whether and how to fight deflation. This sub-section examines the Bank of Japan's actions to fight deflation from 1998 (the birth of new Bank of Japan) to mid-2004. I identify four stages of action in the period from 1998 to 2004 :

Stage 1. Cautiously lowering interest rates to ZIRP: April 1998 - February 1999. Stage 2. ZIRP, lifting ZIRP and return to ZIRP: February 1999 - March 2001. ZIRP "until deflationary concerns are dispelled".

Stage 3. Quantitative easing (QE), phase 1: March 2001 - March 2003. QE until CPI inflation rate becomes "stably above zero".

Stage 4. QE, phase 2: March 2003 - present. QE until CPI (excluding fresh food) is positive for a few months and is expected to remain positive in the future.

Stage 1. April 1998 - February 1999

When a new team took over the newly-independent Bank of Japan, there was a high hope that proactive actions would be taken and that the Bank would take accountability for its actions. Price stability became the stated mandate, rather than the de facto mandate. The Bank does not have to listen to, or try to guess the judgement of, the government on how monetary policy should be conducted, so that price stability should be genuinely pursued. However, in retrospect, the timing of independence was less than perfect or even unfortunate. The economic outlook was quickly deteriorating, due to the banking crisis and the lingering aftershocks of the Asian currency crisis. The yen was depreciating, reflecting a pessimistic mood towards prospects for the Japanese economy and the financial sector. Additional policy measures, both monetary and fiscal, had to be prepared.

In many MPMs, Mr. Nakahara proposed to lower the call rate. For example, in July, he proposed that the Bank lower the interest rate to 0.35 per cent, and in the August 11 meeting, he proposed 0.25 per cent. On both occasions his proposal was defeated, with 1 vote in favour and 8 against. ${ }^{15}$

On 9 September 1998, the Bank of Japan decided to lower the policy interest rate (the uncollateralized overnight call rate) to, on average, around 0.25 per cent. ${ }^{16}$ However, negative growth was recorded in the second half of 1998, and the Bank finally decided to adopt the zero interest rate policy in February 1999.

Stage 2. ZIRP, lifting ZIRP and Return to ZIRP: February 1999 - February 2001

The statement of the monetary policy decision on 12 February 1999 read as follows:

The Bank of Japan will provide more ample funds and encourage the uncollateralized overnight call rate to move as low as possible.

15 In the description of discussions in the minutes, individual names are not disclosed. However, the name of the Board member who proposed a vote and the names of those who voted in favour and against are disclosed. So, in the case relating to 1-8 votes, one can guess who expressed the minority opinion in the discussion prior to the vote. By this process of deduction, we know that Mr. N. Nakahara has been consistently the "dove", and Ms. E. Shinotsuka the "hawk". $16 \mathrm{Mr}$. Nakahara voted with the majority in favour of the proposal, but Ms. Shinotsuka voted against, insisting that the interest rate should not be lowered. 
To avoid excessive volatility in the short-term financial markets, the Bank of Japan will, by paying due consideration to maintaining market function, initially aim to guide the above call rate to move around $0.15 \%$, and subsequently induce further decline in view of the market developments (The Bank of Japan, Announcement of the Board Decision, 12 February 1999).

This was the beginning of the zero interest rate policy (ZIRP). It was clear that the economy was in a very weak state. At the time it was thought that GDP had recorded five consecutive quarters of negative growth since 1997:4. (In later revisions to the GDP data, the consecutive quarters of negative growth disappeared. ${ }^{17}$ )

No additional actions were taken between February 1999 and the fall of 1999. From the summer to the fall of 1999, output remained basically flat. The government and business circles started to voice their concern with deteriorating conditions and called for the Bank of Japan to adopt a more aggressive monetary policy, dubbed quantitative easing. Just before the 21 September 1999 meeting of the Policy Board, some press speculated that the Board would decide to take some actions, most likely non-sterilized intervention in the foreign exchange market in cooperation with the Ministry of Finance. The market regarded non-sterilized intervention as a signal by the Bank of Japan for further action.

The Policy Board reacted strongly to the press speculation. The Board issued its statement at the conclusion of the meeting. At the time, the Governor's press conference was scheduled only two days after the Board meeting, so that the immediate response itself was a message. In the announcement, the Board emphasized that monetary policy would not respond to exchange rate movements and that non-sterilized intervention was not a useful policy. The Board strongly warned that the press was greatly mistaken in engaging in speculative reporting before the meeting: "In the past few days, the market has substantially fluctuated by speculations on monetary policy. What should be clear is that the conduct of monetary policy is exclusively decided by majority vote at the Monetary Policy Meeting, a regular meeting of the Policy Board. It is never the case that our policy is determined in advance or in consultation with outside bodies. We would like to emphasize this point" (Bank of Japan, "On the Current Monetary Policy", 21 September 1999). The comment seemed to show the irritation and frustration that was felt by the Board. Any prior reporting of the expected decision was considered to be a challenge to independence. The Board successfully extinguished any expectation in the market that policy would accommodate the desires of the government or the markets. Any doubt about independence was thus clearly erased. However, such a strong statement might also have indicated a sense of insecurity on the part of the new Bank of Japan. The Bank's assertion of its righteousness, and its shutting out any external suggestions , prompted increased calls for accountability.

The Board took the view that the exchange rate was one of the variables that should be monitored, but that monetary policy should not respond to exchange rate movements per se. ${ }^{18}$ The Board then explained that non-sterilized intervention was

17 At the time of spring 1999, the growth rate for the five quarters from 1997:4 to 1998:4 was estimated as negative. The current (spring of 2004) estimates for the same period are $0.7,-1.0,-1.1$, 0.8 and 0.1 .

18 "The foreign exchange rate in itself is not a direct objective of monetary policy. One of the precious lessons we learned from the experience of policy operations during the bubble period is that, monetary policy operations linked with control of the foreign exchange rate runs a risk of 
not a useful concept for the central bank that watches total funds in the market, whatever various sources they came from. ${ }^{19}$

The Board indicated that it had done enough to ease monetary conditions, and it even cited the "side-effects" of ZIRP. The Board also challenged the market expectation that non-sterilized intervention would be pursued. This was indicative of their desire to end the ZIRP as soon as possible. ${ }^{20}$

No additional easing was adopted between the fall of 1999 and the summer of 2000, except for liquidity injections to deal with Y2K concerns. In the spring of 2000, Governor Hayami started to suggest that the ZIRP may end soon, as the economy showed some signs of recovery. Stock prices in particular were suggesting a rosier situation: ICT-related stock prices had soared, some tripling in a year, and the Nikkei 225 index had increased by 30 per cent between March 1999 and March 2000. Corporate profits rose and corporate investment started to increase. Some Bank economists suggested that these corporate earnings would trickle down to households to stimulate consumption sooner or later. ${ }^{21}$ This argument was dubbed the "dam theory": water (profits) was filling up the corporate dam and would overflow to downstream (household's income) sooner or later.

By June, Governor Hayami was frequently suggesting that there were bright signs in the economy so that the ZIRP can and should be ended soon. Yet many economists thought that ending ZIRP would be premature. They called for an easing of monetary policy, or quantitative easing, while the Bank of Japan was looking at tightening of monetary policy - not a healthy situation.

The ZIRP was indeed lifted on 11 August 2000, as the Board decided that the deflationary concern was over. ${ }^{22}$ However, it was realised at this time that the further

leading to erroneous policy decisions. Having said this, it does not mean that monetary policy is pursued without any consideration to the development of the foreign exchange rate. The Bank considers it important to carefully monitor the development of the foreign exchange rate from the viewpoint of how it affects the economy and prices" (Bank of Japan, "On the Current Monetary Policy" 21 September 1999).

19 "In relation to the foreign exchange rate policy, we have heard arguments in favor of nonsterilized intervention. In the reserve market, however, there are various flows of funds such as currency in circulation and Treasury funds other than those resulting from the intervention. The Bank conducts its daily market operations taking into account all the money flows, in order to create ample reserves to such an extent as described above. This strong commitment of fund provision is consistent with the government's current foreign exchange rate policy" (Bank of Japan, "On the Current Monetary Policy" 21 September 1999).

20 "The Bank views the current state of the Japanese economy as having stopped deteriorating with some bright signs, though a clear and sustainable recovery of private demand has yet to be seen. In pursuing the zero interest rate policy, we need to carefully examine its adverse sideeffects, but deem it important to support the economic recovery by continuing easy monetary policy for the periods ahead" (Bank of Japan, "On the Current Monetary Policy", September 21, 1999).

21 "Currently, it is our judgment that Japan's economy is at the stage where the number of firms taking the offensive has started increasing, that is, the economy is moderately recovering parallel with structural adjustment. ... with respect to the recovery of private demand, it seems natural that the corporate sector, which has regained profitability as a result of restructuring, should take the lead by increasing investment followed by the household sector as income conditions gradually improve. This is the development we are now witnessing" (speech given by Masaru Hayami, Governor of the Bank of Japan, at the Japan Center for Economic Research on May 29, 2000, http://www.boj.or.jp/en/press/00/ko0005b.htm\#0103 ).

22 Governor Hayami intended to raise the interest rate in July. However, a large department store, Sogo, failed and the economy showed some weakness. The plan of lifting the interest rate was postponed without being submitted to the meeting. 
recovery of the Japanese economy was in doubt. First, the ICT bubble had already burst, and ICT stock prices in the US and Japan had already crashed, suggesting investment and consumption would be adversely affected in the near future. Second, the US economy was decelerating. Third, and most importantly, the inflation rate was still negative and projected to be negative for at least a year. How could the Bank of Japan tighten policy when the inflation rate was negative?

The government disagreed with the Bank on the outlook for the economy and appropriateness of raising the interest rate, and motioned that the vote to repeal ZIRP should be delayed. Putting forward a proposal of delay in voting by the government representative is allowed in the Bank of Japan law. The government motion was overruled by the Board by an 8 to 1 vote. The lifting of the zero interest rate policy was then decided by a 7 to 2 decision.

Immediately after the ZIRP was ended, the Japanese economy entered recession. The growth rate in 2000:3 turned negative, which was offset to some extent by a brief recovery in 2000:4. The peak of the business cycle was later dated as October 2000. As the economy entered recession, the criticism of the Bank of Japan's actions increased once more.

Many indicators were showing weakness in the last quarter of 2000, and the Bank started to examine ways to ease monetary policy. In February 2001, the Bank introduced the so-called Lombard lending facility and also cut the official discount rate from 0.5 per cent to 0.35 per cent. The Lombard lending facility facilitated automatically lending to banks with collateral at the official discount rate, so that the interest rate would be capped at 0.35 per cent. But the call rate was around 0.2 to 0.25 per cent, and consequently there seemed to be little impact from the introduction of the Lombard facility. A dramatic switch in monetary policy followed.

\section{Stage 3. Quantitative Easing, phase 1: March 2001 - March 2003}

The MPM of 19 March 2001 turned out to be significant in several respects. First, it effectively restored ZIRP by adding liquidity to the inter-bank market for excess reserves. The target inter-bank rate was lowered immediately to 0.15 per cent, and would go down to zero, as conditions warranted. The official discount rate was also cut to 0.25 per cent. Second, the announcement of the instrument switch from the interest rate to the current account balance (the sum of required and excess reserves) at the Bank of Japan suggested that further steps expanding the monetary base, as part of a quantitative easing policy, would be taken in the future if they were considered necessary. Third, the new relaxed monetary policy was to continue until the CPI (excluding fresh food) inflation rate would stabilise above zero.

The target of the current account was set at 5 trillion yen. However, by targeting an amount beyond required reserves (about 4 trillion yen) it effectively meant that the inter-bank rate (i.e., the call rate) would go to zero, and so it did. Targeting the current account beyond 4 trillion yen meant targeting excess reserves. ${ }^{23}$

From March 2001 to March 2003, quantitative easing was expanded in several steps. In August 2001, another measure of quantitative easing was employed. The amount of BOJ outright purchases of long-term government bonds was raised from 400 billion yen per month to 600 billion yen per month. At the same time, the current

23 In March 2001, before it was adopted, BOJ economist, Mr. Okina (1999b) reviewed the excess reserve targeting as a possible next step in monetary easing. He pointed out a few problems with this option. First, "what kind of function can be expected of excess reserves" is not known with certainty and it was identified as a problem. Second, excess reserves is not reliable "as an indicator for monetary easing". Third, Dr. Okina pointed to an operational hurdle. 
account target was raised to 6 trillion yen (or about 2 trillion yen excess reserves). In September 2001, the official discount rate was cut to 0.1 per cent, but this did not have any impact given that there was ample liquidity in the form of excess reserves. In December 2001, the monthly purchase of long-term bonds was increased from 600 billion yen to 800 billion yen and the current account target was raised to 10-15 trillion yen. In February 2002, the monthly purchase of long-term bonds was increased from 800 billion yen to 1 trillion yen. In October 2002, the monthly purchase of long-term bonds was raised to 1.2 trillion yen from 800 billion yen, and the current account target was raised to 15-20 trillion yen.

\section{Stage 4. Quantitative Easing, phase 2: March 2003 - present}

In March 2003, at the time of the expiration of terms, a new team of Bank Governor and Deputy Governors were appointed. The new Governor Fukui was a former Deputy Governor, before he resigned in March 1998. An ex Ministry of Finance official, Mr. Muto, and a professor of economics, Mr. Iwata, were appointed as the two Deputy Governors. Mr. Iwata was known to have advocated inflation targeting while he was the Director General of the Cabinet Office.

Almost from the beginning the new team gave a sign that it would work with the government in fighting deflation: Governor Fukui was sending a message that he would continue ZIRP for a long period of time. His tone was much more supportive of ZIRP than his predecessor. The market was thus much more assured of sustained ZIRP in the future.

In his speech to the Japan Society of Monetary Economics, Governor Fukui (2003) explained the effects of the monetary policy framework he inherited in a way that was much closer to mainstream economists' thinking outside the Bank of Japan. The increase in the quantitative easing was aimed at the portfolio balance effect: as "the marginal value of liquidity services became zero, people would start to rebalance their portfolios by investing in assets with higher marginal values whether these were real or financial assets, if the Bank increased further its position of liquidity. The aim of this process was thus to generate positive economic momentum, acting, for example, to push up asset prices. So far, however, the effect has not been widely observed". This is quite consistent with the view outside the Bank, but different from discussions in the Policy Board under the previous regime, in which even the slightest inflation was considered to be bad because, by helping debtors, it delayed structural reform. Governor Fukui also described the increase in long-term bonds as a successful operation, contributing to "the smooth implementation of quantitative easing". He also explained the commitment to continuing ZIRP and quantitative easing as a strong one, because even if the future inflation rate was expected to be positive, the ZIRP would continue as long as the current CPI (excluding fresh food) inflation rate is below zero. Considering the lag in the effects of monetary policy, he suggested that the policy could end up tolerating inflation. This kind of presentation also sounds close to what was being advocated by supporters of inflation targeting, although Governor Fukui stopped short of embracing inflation targeting.

After Mr. Fukui became Governor, the target amount of the current account was raised in several steps from 17 to 22 trillion, to 30 to 35 trillion between March 2003 and January 2004. In October 2003, the Board elaborated on the two necessary conditions to end the ZIRP. Essentially, these are: (1) the CPI (excluding fresh food) inflation rate is "zero percent or above" as a trend "for a few months"; and (2), the 
prospective CPI is not expected to be "below zero percent" according to forecasts of "many Policy Board members". 24

In the next few subsections, the changes in monetary policy actions are summarized according to the instruments of monetary policy.

\subsection{Quantitative Easing and Unconventional Monetary Policy}

As mentioned above, the Bank adopted quantitative easing in March 2001, and increased its amount of outright purchases of long-term government bonds. The monthly purchase was raised from 400 billion yen before March 2001, to 12 trillion yen in October 2002. It is somewhat remarkable that Governor Hayami, who seemed to have opposed easing and also led the move to lift the ZIRP in August 2000, had changed the position and implemented the increase in government bond purchases after March 2001. Although excess reserve targeting was introduced in March 2001, it was increased from 5 trillion to 15-20 trillion in October 2002. Most of the jump in excess reserves came under the Governor Fukui's leadership after March 2003. The measures of long-bond purchases and the Bank of Japan's target for current account balances are summarized in Figure 4. The chart shows the increase in purchases of long-term bonds and the current account balances target over time.

In terms of the two options of increasing the purchase of long bonds and increasing excess reserves, the former is believed to have an immediate impact on the economy, through lowering (or preventing the increase in) the long-term interest rate, and forcing portfolio shifts among private-sector investors. An increase in the purchase of long bonds had been implemented between April 2001 and October 2002, the last two years of the Hayami regime, and the amount of monthly purchases has remained the same since Mr. Fukui became Governor. Mr. Fukui was more aggressive in increasing the target for current account balances at the Bank of Japan.

\subsection{ZIRP and Exit Conditions}

The ZIRP was adopted on 12 February 1999, and Governor Hayami elaborated on the conditions when it would be ended in his speech two month later (in the press interview of the Governor, on April 13, 1999, available in Japanese only on BOJ homepage). But, neither he nor the Board defined what "deflationary concerns" meant or when and under what conditions they would be judged to be "dispelled".

\footnotetext{
24 The announcements on October 10, 2003 read as follows: "With the aim of laying the foundation for sustainable growth of Japan's economy, the Bank is currently committed to maintaining the quantitative easing policy until the consumer price index (excluding fresh food, on a nationwide basis, hereafter the core CPI) registers stably a zero percent or an increase year on year. Such commitment is underpinned by the following two conditions. (Para.) First, it requires not only that the most recently published core CPI should register a zero per cent or above, but also that such tendency should be confirmed over a few months. (Para) Second, the Bank needs to be convinced that the prospective core CPI will not be expected to register below a zero per cent. This point will be described in such materials as the analysis and the forecasts of Policy Board members in the Outlook Report. To be more specific, many Policy Board members need to make the forecasts that the core CPI will register above a zero per cent during the forecasting period. (Para.) The above conditions are the necessary condition. There may be cases, however, that the Bank will judge it appropriate to continue with quantitative easing even if these two conditions are fulfilled". Calling the CPI excluding fresh food as core CPI may be misleading because it still contains energy prices.
} 
The Bank had also not decided which price indicator should be used to define inflation/deflation or the number that would be a threshold of inflation/deflation. ${ }^{25}$ The word "deflation concerns" left room for an interpretation that the economic conditions at the time may not be in the state of deflation. Many economists contended that the economy was already in the state of deflation. But the Bank, and the Governor, was perhaps indicating that the problem was concern about, rather than the reality of, deflation.

In 2000, the ZIRP was lifted, as the exit condition was met, as judged by majority of the Board members. In the Minutes of August 11, 2000, the reason for judgement is explained as follows:

On the current economic situation, members shared the view that the economy was recovering gradually, with corporate profits and business fixed investment continuing to increase. As for the outlook for the economy, many members expressed the view that the economy was likely to recover gradually, led mainly by business fixed investment. Accordingly, the majority of members agreed that the economy had reached the stage where deflationary concern had been dispelled.

It is surprising that the above paragraph does not mention any price movements in the past or future. Deflationary concern was judged to have been dispelled, because of economic recovery (real GDP movement), corporate profits, and business fixed investment. Although one could interpret the paragraph as a forward-looking inflation judgement - economic recovery results in price increases - there is no explicit mention of this linkage. A more likely interpretation was that the Board members at that point were not using the price movement as the guide to their policy, because price declines due to "supply side factors"; that is, technological innovations and cheap imports are a good thing.

The Bank of Japan was also responding to new calls for a more careful definition of price stability. On 13 October 2000, two months after raising interest rates, the Policy Board issued a report called "On Price Stability". In the document, price stability was defined as a state that is neither deflation nor inflation. This apparent tautology did not help settle the debate.

When the ZIRP was effectively reintroduced in March 2001, the condition became more concrete: the CPI index excluding fresh food was identified as the right price index on which to focus. The relaxed monetary policy would continue until the inflation rate measured by the CPI excluding food would become "stably above zero". However, what "stably above zero" meant was not defined. But, at least, it specified that the inflation rate had to be positive at the time of ending ZIRP.

Clearly, if this condition had been applied from the beginning, the ZIRP would not have been lifted in August 2000. Therefore, it can be understood that introducing such a condition was a tacit admission that the action of August 2000 was a mistake. The condition was further clarified in October 2003.

In October 2003, "stably" was further defined as above zero for a few months and when there would be no risk of falling back into deflation. Also, while these two

25 "Price indicators such as the GDP deflator, CPI, and Wholesale Price Index (WPI) often move differently. Even when these indicators exhibit the same movement, the extent to which the sound development of the national economy will be achieved may depend on such factors as whether property prices are stable or rising sharply" (Okina, 1999, p.164). 
conditions were explicitly mentioned as necessary conditions, they may not be sufficient.

In summary, the exit conditions from ZIRP and the definition of price stability have changed over time, as follows:

(1) February 1999. Adoption of de facto ZIRP.

(2) April 1999. Exit condition was "until deflationary concerns are dispelled".

(3) August 2000. Exit from ZIRP.

(4) October 2000. A document on "On Price Stability" was issued. Price stability was defined as a condition where there is no inflation or deflation.

(5) March 2001. Return to ZIRP with a new exit condition: "until the CPI (excluding perishables, on a nationwide basis) registers stably a zero percent or an increase year on year".

(6) October 2003. Elaboration of exit conditions as the two necessary conditions, a backward-looking one, the inflation rate has to be, on average, at a zero percent or above for a few months, and a forward-looking one, the inflation rate should be projected not to fall back to deflation.

One might ask whether these exit conditions constitute de facto inflation targeting. As the inflation indicator is specified and at least the inflation target floor rate is mentioned, the commitment seems to be a half step toward inflation targeting. But there are four important reasons why we should not regard the exit conditions as a full-fledged inflation targeting. First, the inflation target ceiling rate is not specified. Second, the projected date when the Bank would like to achieve its target is not specified. Third, the conditions are more reactive than proactive: the Bank is not expressing that it would do everything it takes to achieve the inflation rate. Instead, it reads that the conditions may occur with luck or some forces external to the Bank's actions. Fourth, no accountability mechanism is attached to the current exit condition.

\subsection{Purchases of Equities and REITs}

Some economists outside the Bank advocated that the Bank purchase riskier assets than government bonds, including the listed market-based stock index funds and the listed real-estate investment trust funds (REITs). The Bank has refused to take these unconventional policy actions on several grounds. It was argued that these are risky assets that the central bank would not normally purchase, and that they are also more like fiscal operations rather than monetary operations. Piling up risky assets in the central bank balance sheet was also suggested to be a bad idea, since it may result in a situation in which the Bank would run huge losses and lose the confidence of the people.

However, in September 2002, the Bank of Japan started to purchase equities held by commercial banks. This policy was introduced to reduce the risks of stock price fluctuations on commercial banks' balance sheets and, as a result, their riskbased capital ratios. The policy was intended to contribute to financial market stability. The Bank of Japan was careful to discuss this in the regular MPM, as opposed to the Monetary Policy Meeting. The ceiling for purchases was set at 2 trillion yen initially, but expanded later to 4 trillion yen. As stock prices dropped from the time of implementation (October 2002) to May 2003, a lot of purchases were made, but after stock prices started to recover from the trough, commercial banks held on to equities.

\subsection{Unsterilized Intervention}


A number of economists have advocated foreign exchange interventions as one expansionary measure that the central bank and the Ministry of Finance could undertake at the zero interest rate. Two explicit benefits have been cited. First, intervention would lead to a depreciation that would stimulate the export sector and increase imported prices (which is good for an economy suffering from deflation). Second, foreign bonds purchased could be used as assets against which monetary base can be provided to the market. Increasing the monetary base by buying foreign bonds is essentially unsterilized intervention. In normal circumstances, when the interest rate is positive, the standard textbook story is that sterilized intervention may not work, because the interest rate would not change, and unsterilized intervention would work, because the increased monetary base would lower the interest rate. However, at a zero interest rate, the interest rate channel disappears. Whether one thinks that unsterilized intervention has a greater effect than sterilized intervention, even at a zero interest rate, then becomes equivalent to a question of whether quantitative easing, in terms of increasing monetary base, is effective or not.

Svensson (2001) was explicit in recommending unlimited unsterilized intervention to peg the yen/dollar rate at a depreciated level to stimulate export demand. There are some complications to this kind of proposal. First, Japan is a large economy that is already running current account surpluses. An explicit depreciation policy and more exports may not be politically acceptable, as argued in Ito and Mishkin (2004). Another complication is that foreign exchange interventions are conducted by the Ministry of Finance in Japan, so that unsterilized intervention has to be coordinated between the Ministry of Finance and the Bank of Japan.

When several proposals were made for interventions during the zero interest rate policy in 2000-2002, interventions were rare events (see Ito (2003) for discussion of the effectiveness of sterilized interventions from 1991 to 2002). However, from January 2003 to March 2004, interventions suddenly became quite frequent and of a large size. In 2003, periodically intervention looked unsterilized, as the amount of intervention and changes in monetary base were running neck to neck (see Ito 2004). For example, the accumulated intervention and increase in money supply were, respectively, 2.3 trillion yen and 1.7 trillion yen for 2003:1; 4.5 trillion yen and 6.1 trillion yen for 2003:2; 7.5 trillion yen and 0.9 trillion yen for 2003:3; and 5.9 trillion yen and 3.9 trillion yen for 2003:4. For the calendar year 2003, accumulated intervention was 20 trillion yen and the increase in monetary base was 12.6 trillion yen. But, if the increase in the monetary base of 9.2 trillion for 2002:4 (when there was no intervention) was added to the increase in the monetary base, the two figures become about equal for the period from 2002:4 through 2003:4. Although the correspondence was most likely a coincidence rather than planned, it did provide a signal of the Bank's willingness to cooperate. (In 2004:1, there was another 15 trillion yen worth of intervention, while the monetary base increased by less than 1 trillion yen.) In September 1999, any suggestion of unsterilized intervention was strongly rejected by the Bank, while in 2003, Deputy Governor Iwata himself pointed out the correspondence, although he concluded that "it must be a coincidence". ${ }^{26}$

\section{Inflation Targeting}

In this section, the pros and cons of adopting Inflation Targeting (IT) in general, and under the deflationary environment in Japan in particular, are considered.

26 Iwata, Press interview, October 1, 2003 in Sendai. The original is in Japanese, http://www.boj.or.jp/press/03/kk0310a.htm. 
The Bank of Japan (including most Board members and staff economists) has consistently argued against the adoption of IT, and that is a major reason why IT has not been introduced. Reasons that have been expressed by the Bank of Japan for not adopting IT are examined in the discussion below.

In the following, I will not make sharp distinctions between inflation targeting and price-level targeting, unless necessary.

\subsection{Inflation Targeting Proposals from Academics}

Inflation targeting was proposed in Japan in the context of fighting deflation and the (near-) zero interest rate. One of the problems associated with the (near-) zero interest rate bound is that as deflationary expectations deepen, the real interest rate increases. The higher real interest rate discourages investment and consumption and exacerbates the deflation problem. Therefore, in order to break the deflationary cycle, many economists thought that managing expectations was very important.

Krugman (1998) was probably the first to suggest some sort of inflation targeting. The essence of his argument was that the Bank of Japan had to promise a high inflation rate later to influence inflation expectations. Raising expectations regarding inflation helps to stimulate current economic activity by reducing the real interest rate, As the commitment device, he proposed an inflation target. After some calibration, he called for 4 per cent inflation for 15 years.

Ito $(1999,2001)$ proposed that the Bank of Japan adopt inflation targeting. As an independent central bank, accountability is needed, and inflation targeting is beneficial in that regard. It would also enhance instrument independence. Moreover, inflation targeting is an effective way to influence inflation expectations. With a zero interest rate, changing inflation expectations is the most effective way to avoid high real interest rates. ${ }^{27}$

Svensson (2001) presented his foolproof way of escaping the liquidity trap at the Bank of Japan conference in July 2000. The paper recommended fixing the exchange rate at the depreciated yen/dollar rate until the price level catches up with the target, and then allowing the yen to float again. The kick start for inflation comes from depreciation of the yen, and price-level targeting spells out the exit condition.

Bernanke (2003), McCallum (2000, 2003), Eggertsson and Woodford (2003), and Meltzer (2001) also offer advices to the Bank of Japan in line with monetary base expansion with resulting depreciation of the yen, and/or some form of inflation targeting or price-level targeting. See Svensson (2003) and Ito and Mishkin (2004) for the literature survey.

Ito and Hayashi (2004) argued for the desirability of adopting inflation targeting. Ito and Mishkin (2004), among other things, advocated a particular type of inflation target, namely the price level target in order to make monetary policy more history-dependent.

Many economists recommended that the Bank of Japan announce a low but positive target range, such as a 1 to 3 per cent CPI inflation rate, and the Bank also announce its willingness to adopt policy to achieve the target in the medium run, say in two years. The positive inflation target is consistent with the legal mandate of price stability, because: (1) the price index has an upward bias; (2) having a buffer to zero is important given a combination of deflation and zero bound interest rate is a serious

27 The Op-ed piece by Ito (1999) was answered by the Bank economist, Okina (1999) in the same space. The Board member, Ueda (2000), supported the Okina's view several months later in another Op-ed piece. 
problem; and (3) a positive inflation rate makes it easier to realize necessary relative price and relative wage adjustments (recall the Akerlof, Dickens, and Perry argument).

\subsection{Why the Bank of Japan Should Have Adopted Inflation Targeting}

The arguments of inflation targeting advocates in Japan can be summarized as follows.

(1) Accountability and Transparency. Since the Bank of Japan became legally independent in April 1998, it has needed to be accountable for its actions. The mandate was clearly price stability, as mentioned in Article 2. But without a concrete definition of price stability, it is hard to assess whether the Bank has acted appropriately. A numerical target - either a point with tolerance band around it like the United Kingdom or a range like New Zealand - would help to clarify the meaning of price stability. Once a target, either a point or a range, is clarified, policy actions can be easily explained, in the context of trying to achieve the target in the medium run. Actions become transparent, and communication with the market becomes easier.

(2) Instrument Independence. If and when the Bank of Japan commits to the specific goal of an inflation target, how to achieve it should be completely left to the Bank. This is called instrument independence. As the Bank will be accountable for the consequences of its actions, the government would not need to pressure the Bank on specific policy measures. The Bank would also not have to respond to criticism or pressure and would not need to become so defensive about critics' arguments on what kind of policy actions should be taken. In other words, the situation like September 1999 would be avoided, or even if pressure comes, the Bank could divorce itself from the controversy.

(3) Impacts on Inflation Expectation. The fundamental problem faced by the Japanese economy since mid-1990s (recall section 1) has been a cyclical problem of deflation, combined with the interaction between deflationary expectations and the zero interest rate bound. The more pessimistic outlook on deflation meant higher real interest rates and depressed economic activity. Available policy tools, monetary and fiscal, are limited, and the best bet for breaking deflationary expectations is to adopt and commit to a positive rate of inflation target. Combined with adopting unconventional monetary policy, an inflation target will also help influence the public's expectations. It may not have an immediate, tangible impact on inflation expectations, but with continued reference to it and policy measures implemented to achieve it, the impact would become stronger. The UK experience shows that the combination of independence and an inflation target would be a powerful weapon to stabilise inflation expectations at around the target inflation rate. ${ }^{28}$

\subsection{Political Economy of Why the Bank of Japan Did Not Adopt Inflation Targeting}

According to the minutes of the Monetary Policy Meeting (MPM) discussions (disclosed about one month after the meeting), inflation targeting was sometimes discussed quite intensively, but, in general, there was an intermittent level of interest. In order to quantify the interest of the Board in inflation targeting, I have counted the number of times "inflation target[ing]" or "target of inflation rate" was mentioned in the recorded minutes for the period of 26 March 1998 to June 2004. Figure 5 shows

28 See HM Treasury (1999, p.29). 
the number for each MPM discussion. The minutes from March 1998 highlight the waves of interest in inflation targeting. A detailed examination of each MPM meeting when inflation targeting was significantly discussed and my comments on the discussion are in the Appendix.

The first wave was from the mid-1999 to the spring of 2000. At this stage, Mr. Nobuyuki Nakahara, a Board member, consistently proposed adopting inflation targeting, but was always voted down by 1 to 8 votes. According to discussions at the Monetary Policy Meetings and speeches of Board members, the majority of the Board held the following view. Deflation was not that undesirable as long as reflected technological innovation and cheap imports. Moreover, when technological innovation puts downward pressure on prices, it is difficult to select an appropriate price index and to define price stability, let alone the numerical target of inflation. However, there was growing pressure from the academic community for the Bank to adopt inflation targeting. According to the minutes of various meetings, the majority of Board members remained sceptical about the merits of adopting inflation targeting. But the increasing interest in inflation targeting inside and outside the Bank led to the decision, on 9 March 2000, to conduct a comprehensive study on price stability. Until the study was done, discussions on inflation targeting were shelved.

The study, "On Price Stability", was discussed on 11 October 2000. The study was not conclusive on any of the issues debated earlier. The report described price stability "as a situation which is neither inflationary nor deflationary". Defining price stability as a state that is neither inflation nor deflation is not a definition, but a tautology. The report acknowledged that a price index had biases, but concluded that it is not easy to obtain a reliable estimate of the magnitude of bias, and that the magnitude can vary. With regard to the question of whether a quantitative definition of price stability was possible, the overall conclusion was negative. The Report was as follows:

(1) In view of the current movement of prices in Japan, an inflation rate which is consistent with the sound development of the economy is likely to be lower in the short term than in the long term.

(2) If some numerical values are adopted as the definition of price stability, they are expected to be valid for a very long period of time. In view of the current development of prices in Japan, it is difficult to set specific numerical values to the definition of price stability that are consistent with the sound development of the economy. Furthermore, even if some numerical values were announced, they would not serve as a reliable guidepost in the conduct of monetary policy, and the exercise would not likely contribute to enhancing transparency of the conduct of monetary policy. Therefore, it is not deemed appropriate to define price stability by numerical values.

(3) While paying due attention to changes in the economy, the Bank of Japan will nevertheless continue to explore whether price stability can be expressed by some numerical values.

After a six-month study, the report basically rejected inflation targeting. It is also notable that in the same MPM meeting, the Outlook with Board members' forecasts of prices and the GDP growth rates in the future was approved. This was intended to enhance transparency. 
The second wave of interest in inflation targeting, between March 2001 and the early 2002, was somewhat intermittent. In March 2001, the Bank re-adopted the ZIRP with quantitative easing. The policy switch was also accompanied by a new commitment strategy that the ZIRP and quantitative easing would continue until the CPI (excluding fresh food) inflation rate stabilized above zero. A comprehensive study reported just six months earlier did not name the CPI excluding fresh food as an appropriate index, but it became the price index to watch after this meeting. The number zero was considered to be inappropriate due to the bias in the price index and the zero nominal bound. Still, the zero became a part of the commitment strategy. There seems to be a distinct change, although in the right direction, from the Report of October 2000 to the commitment strategy of March 2001. Although the March 9, 2001 minutes clearly stated that the commitment strategy was not inflation targeting, mentioning the numerical value prompted a further discussion on inflation targeting in the following months. However, no concrete progress was made, and discussion died out in the early 2002.

The third wave of interest in inflation targeting occurred between October 2002 and January 2003, probably in response to an increasing call for inflation targeting outside the Bank, in anticipation of the expiration of the term of the Governor and two Deputy Governors in March $2003 .^{29}$ There were substantial discussions on inflation targeting on October 10, 2002 and January 21, 2003. A number of reasons against adopting inflation targeting were mentioned. These included: (1) no inflation targeting countrieshad not adopted inflation targeting to increase the inflation rate (January 21, 2003); and, (2), the main benefit of inflation targeting would be to increase inflationary expectations, but since there are no credible policy tools to achieve this, setting a target would impair public confidence in economic policy as a whole. One extreme opinion was recorded as follows: "negative effects on the economy and the financial system, such as damage to the credibility of economic policy and to financial markets, would exceed the positive effects" (MPM 10 October 2002). The Bank of Japan successfully lobbied politicians sympathetic to the Bank's view to have the previous Deputy Governor, Mr. Fukui, who was in the private sector and not voicing any opinions on monetary policy at the time, as the new Governor. ${ }^{30}$

One possibility is that the Bank of Japan, using the term of Cargill, Hutchison, and Ito (2000), fell into an "independence trap". According to these authors, the Bank of Japan was afraid to take bold actions after it had just gained independence. Theoretically, flexible adjustments and bold actions were supposed to have become possible under independence, since actions were at the sole discretion of the Bank Board. On the contrary, the Bank became much more conservative and rigid in taking actions, especially unprecedented ones. They feared that action might be judged a failure later and damage credibility. If this is the case, the Bank of Japan was

29 Some politicians and government officials recommended candidates for Governor who were in favor of inflation targeting to the Prime Ministers' Office. In Governor Hayami's press conference on January 24, 2003, a reporter asked the Governor for his view on inflation targeting, from the background of the political movement that the support for inflation targeting should be a prerequisite for the next Governor. In his reply, Governor Hayami branded inflation targeting as a "reckless bet", which "might make the economy extremely unstable and have side effects and risk". He emphasized that the Bank had expanded the monetary base and taken other actions, and was confident that the economy would recover from deflation without such a bet (press conference, only in Japanese, http://www.boj.or.jp/press/04/press_f.htm).

30 See Fujii (2004; p.283) for an account of the lobbying. 
given independence precisely at the wrong moment because the economy called for unprecedented monetary policy actions.

\subsection{The Economics of the Pros and Cons of Inflation Targeting}

As documented above, and in more detail in the Appendix, most Board members, including Governor Hayami and Deputy Governor Yamaguchi, as well as staff economists at the Bank of Japan, opposed inflation targeting. The arguments against inflation targeting, mostly presented during the Hayami period, will be presented and discussed here. The specific arguments have shifted over time somewhat, but the following seems to be a complete list. Rebuttals from advocates of inflation targeting are also considered. ${ }^{31}$

(1) Reflation Policy is bad, and the inflation rate cannot be controlled.

In the early stage of arguments for inflation targeting, the Bank of Japan contended that inflation was not a solution to Japan's economic problems, and policies to raise the inflation rate may end up achieving a very high inflation rate, even if the aim is a moderate inflation rate. The reasons why moderate inflation was regarded as impossible seem to be two-fold: (1) it was technically impossible; and (2) it was politically irresistible.

One of the early criticisms of inflation targeting was a reaction to the proposal from Krugman (1998) of 4 per cent inflation for 15 years. Inflation targeting was characterized as a simple-minded reflation policy and thus rejected. As it came to be understood that inflation targeting is a flexible framework for monetary policy and that the most likely target range would be somewhere between 1 and 3 per cent, this particular criticism disappeared.

Governor Hayami (2000) categorized inflation targeting proposals in two ways: an inflation policy, as advocated by Krugman, of aiming at 4 to 5 percent; and, a variation of inflation policy, tolerating "a moderate inflation rate of 2 to 3 per cent". He assessed the latter policy as follows:

"it may vitalize economic activity. However, given the current situation in Japan where prices are almost level, such a proposal is tantamount to artificially creating inflation. Furthermore, to implement such a proposal, many have suggested that the Bank of Japan should increase its outright purchase of government bonds or underwrite them. Some even advocate that the Bank of Japan should purchase stocks or real estate. Thus, what started as a proposal aiming at a moderate inflation rate of 2 to 3 per cent under the disguise of inflation targeting for price stability has ended up being the same as inflation policy in that inflation should be artificially created at any cost" (emphasis added by the author).(Section 2)

It is not clear from Hayami's speech what prevents the Bank of Japan from stopping inflation at around 2 to 3 per cent, and why it is technically impossible or politically impossible.

Hayami (2000) argued that "inflation is most likely uncontrollable once triggered". Many argued at that time that it would be possible to pursue a policy aiming at a moderate inflation rate of 1 to 3 per cent. However, in response, Hayami

31 The list is compiled predominantly from MPM Board discussions, summarized in the Appendix, but also press interviews, speeches and articles of the Governor, Deputy Governors, Board members, and staff economists. For the Bank economists' views on related issues see, for example, Okina (1999a, b) Fujiki, Okina and Shiratsuka (2001), Okina and Shiratsuka (2002, 2004), and Okina, Shirakawa, and Shiratsuka (2001). 
commented: "if we tried to contain inflation after it had gained momentum, we would need very strong monetary tightening, which might result in a substantial deterioration of economic activity and a steep climb in unemployment". He seems to be arguing that the optimal and stable inflation rate is zero, and any deviation from it, even a modest amount, would end up in an inflationary spiral that would need strong restraint to end. This might be a reflection of the literature of the early1980s. Indeed, Hayami cited the experiences of the 1970s, where tolerating a small inflation rate triggered a further round of wage and price increases, which spiralled into a higher inflation rate. It was unfortunate that, in the early stage of deflation in Japan, the argument for moderate inflation targeting was dismissed on the ground of a quite dated argument. The experience in the 1990s proved that inflation targeting could anchor expectations, so that it is possible to avoid the wage-price spiral.

(2) No good price indicator.

Inflation targeting is not possible if there is no agreement on which price index should be used and what numbers should be looked at in defining deflation. Some form of the CPI is commonly used by inflation targeters. The menu of choices includes the headline CPI, core CPI excluding fresh food and energy prices, CPI excluding fresh food, or CPI excluding fresh food and rents. In most cases, the difference between the choices is not great, and a reasonably wide band would make the differences among these indices a secondary issue. A possible alternative for a price indicator is the GDP deflator. But it suffers from delayed and infrequent reporting (quarterly instead of monthly), and constant revisions. No inflation targeter has used the GDP deflator. Some form of the CPI would be an appropriate price indicator. However, it took until March 2001 for the Bank of Japan to recognize that point.

The Bank of Japan was hesitant to name a price indicator for judging deflation/inflation. Okina (1999b, p 164) argued that "[p]rice indicators such as the GDP deflator, CPI, and Wholesale Price Index (WPI) often move differently. Even when these indicators exhibit the same movement, the extent to which the sound development of the national economy will be achieved may depend on such factors as whether property prices are stable or rising sharply". Similarly, the "On Price Stability" document, issued in October 2000, did not identify any price indicator as a possible price index. However, the debate was over on 19 March, 2001, when the Bank of Japan decided to use the CPI excluding fresh food as an indicator for a necessary condition to terminate the zero interest rate policy.

(3) No optimal inflation rate can be identified.

When deflation is caused by supply side factors, such as technological innovation and cheap imports, then deflation may be desirable and can be tolerated. This argument was commonplace in 1999 and 2000 (recall earlier discussions in section 2.1).

Advocates of inflation targeting have pointed out that this argument confuses the relative price phenomenon - prices of goods subject to technological innovation would fall relative to other goods and services, but the average price level would remain predominantly a monetary phenomenon. In addition, a combination of low growth with declining prices is better explained by demand factors than supply factors.

Advocates of inflation targeting insist that price stability can be defined as a reasonable range, such as a medium-term range of 1 to 3 per cent, which allows for 
sufficient flexibility if prices are influenced by supply side factors and temporal shocks. The 1 to 3 per cent target has been popular among inflation targeters, such as Canada and Sweden. The United Kingdom now has a target of 2 per cent in CPI with a tolerance range of plus/minus 1 per cent. ${ }^{32}$ The floor of the target, 1 percent, is designed to allow for the upward bias of the price index and to provide a buffer against deflation. The buffer also helps to ensure that the economy would not instantly fall into deflation if it was hit by negative demand shocks, and thereby exhaust the conventional instrument (the interest rate) too quickly.

Economists at the Bank of Japan for a long time have argued that it is difficult to identify a specific number as a target inflation rate (or range). In short, they argue that the optimal inflation rate would vary depending on the type of shocks to the economy. Hayami (2000) basically argued that a desirable inflation rate varies from country to country, and it was probably lower in Japan than other countries. He provided two reasons for this. First, deflation in Japan reflected supply side shocks, and when such shocks lead to lower prices, deflation may be desirable. Second, since wages are flexible in Japan, output losses a la Akerlof, Dicken and Perry (1996) would be small. Moreover, in terms of the lower end of the range as a buffer against deflation, Hayami (2000) stated that " $[\mathrm{t}]$ he idea of tolerating a certain positive rate of inflation to ensure a cushion for monetary policy seems to be something like putting the cart before the horse".

On October 13, 2000, two months after raising interest rates, the Policy Board issued a report called "On Price Stability". In the document, price stability was defined as a state that is neither deflation nor inflation. The document did not mention any numerical number that would define deflation or inflation, and as a consequence, price stability.

The debate moved to a new phase on March 19, 2000, since a zero per cent inflation rate was mentioned as a necessary condition to terminate ZIRP. It seems that the Bank of Japan still regards a zero per cent inflation rate as price stability, but mentioning a particular number was still a sign of some progress. However, while the Bank of Japan still prefers zero per cent as a magic number, other central banks are moving away from zero per cent, precisely due to the buffer argument. New Zealand revised its target range from 0 to 3 per cent to 1 to 3 per cent in September 2002.

(4) Inflation targeting in deflation is unprecedented.

Another popular argument against inflation targeting was that no country had adopted inflation targeting to return to inflation from a state of deflation. ${ }^{33}$ However, no other major country has faced sustained deflation in the post-war period. As such, the fact that "no country has done it" is not a valid argument against the proposal.

During the Depression of the 1930s, many countries suffered from deflation. Sweden adopted a kind of inflation targeting (to be precise, the price level targeting), when it departed from the Gold Standard. It was an attempt to seek a nominal anchor to avoid deflation (see Berg and Jonung 1999).

(5) Announcement alone will not be credible.

It is often argued that the mere announcement of an inflation target would not change expectations. ${ }^{34}$ In response, advocates of inflation targeting would contend

32 Until December 2003, the target rate was 2.5\%, measured in RPIX index, that is constructed differently and includes costs of owner-occupied housing.

33 The view was expressed in the MPM on January 21, 2003, see the Appendix.

34 The view was expressed in the MPM on January 12, 2001, see the Appendix. 
that, although expectations are the most important and unique channel of inflation targeting, the effects may not be immediate. Having a target, in combination with the use of other measures, such as some degree of unconventional monetary policy, would certainly raise the probability of anchoring expectation faster than otherwise. The loss of credibility, if the inflation target was not achieved - often insisted on by the Bank economists and Board members - has to be balanced against the loss of credibility by not forcibly acting on the deflation problem.

It is certainly true that a mere announcement would not significantly change the public's inflation expectations. The introduction of inflation targets among advanced countries tends to be accompanied by an institutional framework that makes inflation targeting credible and accountable. In several countries, including New Zealand and Australia, inflation targeting is an agreement between the government (typically the Ministry of Finance or Treasury) and the central bank, and both are committed to policy that is consistent with the inflation target. In several countries, including New Zealand and UK, when inflation exceeds the target by a wide margin, the Governor is required to provide an explanation to the parliament. With accountability and commitment, inflation targeting does become credible.

(6) The long-term interest rate will go up.

Another argument against inflation targeting is based on the possibility that inflation targeting could be instantly believed - the opposite scenario to the preceding point. If the public believes in the inflation target of, say, 2 per cent, then the longterm interest rate would increase by 2 per cent, before the economy recovers, which would damage the economy. ${ }^{35}$

Since the long-term interest rate is a compound of future (expected) short-term rates, a belief that inflation targeting would lead to an average 2 per cent inflation rate would raise the long-term interest rate. However, if the amount of a rise in the nominal interest rate is less than the amount of a rise in inflation expectations, then the real long-term rate will fall. Therefore, the nominal interest rate hike per se is not damaging, but the real interest rate hike is. When the economy is in a depressed state, it is more likely that the increase in inflation expectations at the long end of the yield curve would result in a reduction, not an increase, in the real interest rate.

(7) No additional instruments at the zero interest rate.

The opposition to inflation targeting in Japan boils down to the feasibility of adopting available instruments. Those who oppose inflation targeting always raise the issue of no tools being available at the zero interest rate. ${ }^{36}$ Given that the interest rate is zero, no policy measures are available to lift the inflation rate to positive territory, so that the announcement of inflation targeting, without tools to achieve the target, would damage the credibility of the Bank. Therefore, committing to a target when the Bank did not have the tools to achieve it would cause the Bank to lose credibility. ${ }^{37}$

35 This view was frequently mentioned in MPMs and also in speeches. For example, see the MPMs on June 28, 1999 and October 10, 2002. The view was also expressed by Hayami (2000). 36 This view was expressed throughout the period of the Hayami regime by Board members and Bank economists. Early citations include the MPMs on October 13, 2000, and July 12, 2001. See also Oda and Okina (2001: pp. 352-356).

37 "[T] $]$ he BOJ argues, as is recorded in the minutes of Monetary Policy Meetings, that 'since we cannot explicitly show the way to achieve the desired inflation rate, such action would most likely result in the BOJ losing credibility"' (Okina, 1999, p.165). In response, critics argued that as nonconventional monetary policy measures exist that could achieve a positive rate of inflation, the credibility argument is based on incorrect assumptions. 
Advocates have argued that several unconventional instruments, including quantitative easing and aggressive purchases of riskier assets, are available, even at the zero interest rate. Under the guise of quantitative easing, long-bond purchases and increasing the monetary base have been implemented since March 2001. Prior to this, Board members were sceptical about the effectiveness of quantitative easing. In addition, buying foreign bonds, market-based stock index funds, and listed real-estate trust funds, are frequently mentioned as potential measures. The debate would then shift to the appropriateness of unconventional measures. This debate is not covered here, but Ito and Mishkin (2004) provide a survey of the literature, and Ahearne et al (2002) and Bernanke (2002) discuss unconventional instruments in the context of the Federal Reserve Board. ${ }^{38}$

One of the concerns with unconventional policy - purchasing stocks, foreign bonds and real estates - was the possible damage to the Bank of Japan's balance sheet. Prices of risky assets may go down, and the Bank's capital may be depleted and credibility would be lost. Advocates of unconventional policies argued that the Bank balance sheet was not a concern; if the Bank is regarded as a part of the public sector, the consolidated balance sheet with the government would not show a problem. In the extreme case, a capital injection from the government is possible. If inflation targeting had been adopted, it would also be easier to justify the Bank's action of purchasing risky assets. The government would inject capital, as long as the inflation target is met, without asking questions. Thus an additional benefit of inflation targeting, from the accountability viewpoint, is that it would enable the Bank to take bold actions. ${ }^{39}$

Some of these instruments, as they are in the realm of fiscal policy, need the cooperation of the Ministry of Finance. ${ }^{40}$ Foreign exchange intervention is decided and conducted by the Ministry of Finance in Japan. ${ }^{41}$ Most of the foreign reserves in Japan are held in the special account of the government. So, the central bank purchase of foreign bonds can only be achieved by intervention by the Ministry of Finance with an equivalent increase in monetary base. Any short-term government bonds are essentially absorbed by the Bank of Japan, so long as the zero interest rate policy is maintained. As such, so-called "helicopter money" can be dropped into the economy by way of a tax cut financed by the government issuing short-term government bonds. So, at the zero interest rate, the line between monetary policy and fiscal policy is blurred. It is thus essential that the Bank of Japan and the Ministry of Finance cooperate in achieving a common goal, namely getting out of deflation.

\section{Concluding Remarks}

Advocates of inflation targeting have put forward basically three reasons why inflation targeting was a good idea: accountability and transparency; instrument independence; and, effects on inflation expectations. For the third reason, it is particularly desirable for the Bank of Japan to adopt inflation targeting in a

38 See Fujiki, Okina, and Shiratsuka (2001) for the Bank of Japan's view. Views from the US on the Japanese experience are available in Aherne et al (2002) and Clouse (2000).

39 Currently, most of the risk in the Bank's balance sheet arises from the long-term government bonds it holds. An increase in the long-term interest rate would cause unrealized capital losses in these long bonds. Bernanke (2003) proposed that the government substitute the straight bonds that the Bank of Japan holds with floating rate government bonds, in order to protect the Bank's balance sheet from the interest rate risk.

40 This point was made by Robert McCauley during the conference.

41 See Ito (2003) for the institutions of foreign exchange intervention in Japan, and Ito (2004) for intervention records in 2003-2004. 
deflationary environment, as advocates have argued. However, inflation targeting has not been adopted, although some quantitative easing measures that were resisted in early years have been. In examining the reasons put forward by opponents of inflation targeting, it has been shown that, for each item of opposition, there are good rebuttals. Opponents of inflation targeting seem to have prevailed for political economy reasons. Inflation targeting was not adopted in Japan in the early years (the first wave, 1999-2000) because the Board members were not sure which price index would be best, and whether a specific number for an appropriate inflation rate could be determined. A study, commissioned in March 2000, and completed in October 2000, did not give any clear answers to this, and the Bank missed the opportunity. Inflation targeting was not adopted in later years (2001-2003), despite the inflation-targetinglike commitment strategy adopted in March 2001, because the Board members thought that conventional tools to increase the inflation rate were not available. As such, announcing a target with a positive inflation rate would damage confidence just announcing inflation targeting would not increase the inflation rate. In terms of introducing unconventional measures, the Bank of Japan worried about the transmission channels and the damage to its balance sheet. Towards the end of Governor Hayami's term, the views against inflation targeting turned sharply negative, as news reports suggested that it may be linked to the new Governor's appointment. Therefore, , why inflation targeting was not adopted, can be explained and understood from a political economy perspective.

This paper explained why the Bank of Japan hesitated to adopt inflation targeting. In other countries, the adoption of inflation targeting and the setting of a specific numerical target is often done by the Treasury (Ministry of Finance) or by consultation between the Treasury and the central bank. Another question is why the Ministry of Finance did not formally propose the adoption of inflation targeting to the Bank of Japan. One possible explanation is that officials at the Ministry of Finance thought that if the government set the goal that would be viewed as a violation of central bank independence. However, the literature and practice in other countries, such as the United Kingdom, New Zealand, and Australia, shows that goal independence is not an essential part of central bank independence. On the contrary, government involvement in setting the target is considered to be a good way of achieving coordination between fiscal and monetary policy. Another possible explanation why the Ministry of Finance was not pushing the Bank of Japan to introduce inflation targeting was that the Ministry feared that the long-term interest rate would go up sharply by adopting inflation targeting (see Section 3.4.(6)).

As of writing this paper, the Japanese economy seems finally to be getting out of its long stagnation. If the current strength in the economy continues, there is a chance that deflation could be overcome in coming months, rather than years. The necessary conditions to exit from ZIRP - that is, positive inflation rates backward and forward - have been clearly stated since October 2003. When the exit from deflation and ZIRP is achieved, that will be the beginning of a new regime for the Bank of Japan. One of the obstacles to adopting inflation targeting - that is, there are no instruments to achieve positive inflation rates at the zero interest rate policy - will be gone. In order to facilitate accountability in the post-ZIRP area, inflation targeting should be given serious thought. Preparation should be started sooner rather than later. 


\section{References}

Ahearne, Alan, Joseph Gagnon, Jane Haltmaier, Steve Kamin, and others, "Preventing Deflation: Lessons from Japan's Experiences in the 1990s," Board of Governors, International Finance Discussion Paper No. 729, June 2002.

Akerlof, George, Dickens, William, and George Perry, 1996. "The Macroeconomics of Low Inflation," Brookings Papers on Economic Activity 1: 1-59.

Berg, Claes and Lars Jonung (1999). "Pioneering Price Level Targeting: The Swedish Experience 1931-1937," Journal of Monetary Economics, vol. 43: 525-551.

Bernanke, Ben.S. (1983). "Nonmonetary Effects of the Financial Crisis in the Propagation of the Great Depression," American Economic Review 73: 257-76.

Bernanke, Ben.S. (1983). "Nonmonetary Effects of the Financial Crisis in the Propagation of the Great Depression," American Economic Review 73: 257-76.

Bernanke, Ben. S. (2002). "Deflation: Making Sure "It" Doesn't Happen Here," Before the National Economists Club, Washington, D.C. November 21, 2002

Bernanke, Ben S. (2003). "Some Thoughts on Monetary Policy in Japan," Speech before the Japan Society of Monetary Economics, Tokyo, Japan, May 31.

Card, D. and D. Hyslop (1997) "Does Inflation 'Grease the Wheels of the Labor Market'?" in Reducing Inflation: Motivation and Strategy, edited by C.D. Romer and H.D. Romer pp. 71-114, Chicago: University of Chicago Press

Cargill, Thomas; Michael Hutchison; and Takatoshi Ito, (1997). The Political Economy of Japanese Monetary Policy, Cambridge, MA: MIT Press.

Cargill, Thomas; Michael Hutchison; and Takatoshi Ito, (2000). Financial Policy and Central Banking in Japan, Cambridge, MA: MIT Press.

Clouse, James; Dale Henderson; Athanasios Orphanides; David Small; and Peter Tinsley, (2000). "Monetary Policy When the Nominal Short-term Interest Rate is Zero", Board of Governors of the Federal Reserve System, International Finance Discussion Papers, number 729.

Crawford A. and A. Harrison (2000) "Testing for Downward Rigidity in Nominal Wage Rates," in Price Stability, Inflation Targets and Monetary Policy pp. 179-218 Proceedings of a conference held by the Bank of Canada, May 1997 Ottawa: Bank of Canada

Eggertsson, Gauti B. and Michael Woodford (2003), "Optimal Monetary Policy in a Liquidity Trap," NBER working paper, no. 9968.

Fares Jean and Thomas Lemieux (2000) "Downward Nominal-Wage Rigidity: A critical Assessment and Some New Evidence from Canada," in Price Stability and the 
Long-Run Target for Monetary Policy proceedings of a seminar held by the Bank of Canada, June 2000 Ottawa: Bank of Canada.

Fischer, Irving, (1933). "The Debt-Deflation Theory of Great Depressions", Econometrica, Vol. 1: 337-57.

Fukui, Toshihiko, (2003). "Challenges for Monetary Policy in Japan," Speech at the Spring Meeting of the Japan Society of Monetary Economics, June 1.

Fujii, Yoshihiro (2004). Shibarareta Kin-yu Seisaku, (in Japanese, trans. Bounded Monetary Policy), Tokyo; Nihon Keizai Shinbunsha.

Fujiki, Hiroshi; Kunio Okina; and Shigenori Shiratsuka, (2001). "Monetary Policy under Zero Interest Rate: Viewpoints of Central Bank Economists," Bank of Japan, Monetary and Economic Studies, February: 89-130.

Groshen, Erica L. and Schweitzer, Mark E. 1996. "The Effects of Inflation on Wage Adjustments in Firm-Level Data: Grease or Sand?" Federal Reserve Bank of New York Staff Reports, No. 9.

Groshen, Erica L. and Schweitzer, Mark E. 1999. "Identifying Inflation's Grease and Sand Effects in the Labor Market," in Martin Feldstein, ed., The Costs and Benefits of Price Stability University of Chicago Press, Chicago: 273-308

Hayami, Masaru, (2000). "Price Stability and Monetary Policy," Speech to the Research Institute of Japan in Tokyo, March 21. (http://www.boj.or.jp/en/press/00/ko0003b.htm)

Hayashi, Fumio and Edward C. Prescott (2001). "The 1990s in Japan: A Lost Decade" Review of Economic Dynamics, vol. 5: 206-235.

Hoshi, Takeo, and Anil K. Kashyap, (2001). Corporate Financing and Governance in Japan: The Road to the Future. Cambridge, MA.: MIT Press.

Ito, Takatoshi (1992). The Japanese Economy, Cambridge, MA: MIT Press.

Ito, Takatoshi (1999). “A Target for the Bank of Japan,” Financial Times, October 19.

Ito, Takatoshi (2001). Inflation Targeting (in Japanese) Tokyo: Nihon Keizai Shinbunsha.

Ito, Takatoshi (2003). "Is Foreign Exchange Intervention Effective? The Japanese Experiences in the 1990s" in Paul Mizen (ed.) Monetary History, Exchange Rates, and Financial Markets, Essays in Honour of Charles Goodhart, vol. 2, Cheltenham, U.K.: Edward Elgar: 126-153.

Ito, Takatoshi (2004). "The Yen and the Japanese Economy, 2004," in a conference volume edited by John Williamson, Washington D.C.: Institute for International Economics. 
Ito, Takatoshi and Kimie Harada, (2000) "Japan Premium and Stock Prices: Two Mirrors of Japanese Banking Crises” NBER working paper no 7997, November.

Ito, Takatoshi and Frederic Mishkin (2004). "Two Decades of Japanese Monetary Policy and the Deflation Problem," presented at the NBER $15^{\text {th }}$ East Asian Seminar on Economics, Tokyo, June.

Kuroda, Sachiko and Isamu Yamamoto, (2003a). "Are Japanese Nominal Wages Downwardly Rigid? (Part I): Examinations of Nominal Wage Change Distributions," Bank of Japan, Monetary and Economic Studies, vol 21, no.2. August: 1-30.

Kuroda, Sachiko and Isamu Yamamoto, (2003b). "Are Japanese Nominal Wages Downwardly Rigid? (Part II): Examinations Using a Friction Model," Bank of Japan, Monetary and Economic Studies, vol 21, no.2. August: 31-68.

Kuroda, Sachiko and Isamu Yamamoto, (2003c). "The Impact of Downward Nominal Wage Rigidity on the Unemployment Rate: Quantitative Evidence from Japan," Bank of Japan, Monetary and Economic Studies, vol 21, no.4, December: 57-85.

Lebow, David E., Brian Saks, and Beth A. Wilson (1999), "Downward Nominal Wage Rigidity: Evidence from the Employment Cost Index," FEDS Working Paper 1999-31, Board of Governors of the Federal Reserve System, July.

Lebow, David E., David J. Stockton and W. L. Wascher (1995) "Inflation, Nominal Wage Rigidity and the Efficiency of the Labor Market," Board of Governors of the Federal Reserve Working Paper 94-45, October 1995.

McCallum, Bennett T. (2000), "Alternative Monetary Policy Rules: A Comparison with Historical Settings for the United States, the United Kingdom, and Japan," Federal Reserve Bank of Richmond, Economic Quarterly, vol. 86, no.1 Winter: 4979.

McCallum, Bennett T. (2003), “Japanese Monetary Policy, 1991-2001” Federal Reserve Bank of Richmond, Economic Quarterly, vol. 89, no.1 Winter: 1-30.

McKibbin, Warwick J. (2001). "Macroeconomic Policy in Japan," presented for the Harvard University Asian Economic Panel Meeting, Korea, mimeo dated October 16.

Mishkin, Frederic S. 1978. "The Household Balance-Sheet and the Great Depression," Journal of Economic History 38, December: 918-937.

Mishkin, Frederic S. 1991. "Asymmetric Information and Financial Crises: A Historical Perspective," in R. Glenn Hubbard, ed., Financial Markets and Financial Crises, University of Chicago Press: Chicago: 69-108.

Mishkin, Frederic S., 1996. "The Channels of Monetary Transmission: Lessons for Monetary Policy," Banque De France Bulletin Digest No. 27: 33-44. 
Mishkin, Frederic S., 1997. "The Causes and Propagation of Financial Instability: Lessons for Policymakers," Maintaining Financial Stability in a Global Economy, Federal Reserve Bank of Kansas City, Kansas City, MO.: 55-96.

Mishkin, Frederic S., 1998. "Promoting Japanese Recovery," in Kenichi Ishigaki and Hiroyuki Hino, eds., Towards the Restoration of Sound Banking Systems in Japan -the Global Implications (Kobe University Press and International Monetary Fund: Kobe 1998). 130-161.

Oda, Nobuyuki and Kunio Okina (2001). "Further Monetary Easing Policies under the Non-Negativity Constraints of Nominal Interest Rates: Summary of the Discussion Based on Japan's Experience," Bank of Japan, Monetary and Economic Studies, Special Edition, February: 323-369.

Okina, Kunio, (1999a). "The Risks of Single-minded Targeting", Financial Times, November 10.

Okina, Kunio (1999b). "Monetary Policy under Zero Inflation: A Response to Criticisms and Questions Regarding Monetary Policy," Bank of Japan, Monetary and Economic Studies, December: 157-197.

Okina, Kunio and Shigenori Shiratsuka (2002). "Asset Price Bubbles, Price Stability, and Monetary Policy: Japan's experience," Bank of Japan, Monetary and Economic Studies, October: 35-76.

Okina, Kunio and Shigenori Shiratsuka (2004). "Policy Commitment and Expectation Formation: Japan's Experience under Zero Interest Rates," North American Journal of Economics and Finance, vol. 15: 75-100.

Okina, Kunio; Masaaki Shirakawa, and Shigenori Shiratsuka (2001), "The Asset Price Bubble and Monetary Policy: Japan's Experience in the Late 1980s and the Lessons" Background Paper for the conference: Monetary and Economic Studies (special edition) February: 395-450.

Shiratsuka, Shigenori, 1999. "Measurement Errors and Quality-Adjustement Methodology: Lessons from the Japanese CPI," Federal Reserve Bank of Chicago, Economic Perspectives, $2^{\text {nd }}$ Quarter: 2-13.

Svensson, L.O. (2001), "The Zero Bound in an Open Economy: A Foolproof Way of Escaping from a Liquidity Trap," Monetary and Economic Studies, vol. 19, no. S-1, February: 277-312

Svensson, Lars E.O., 2003. "Escaping from a Liquidity Trap and Deflation: The Foolproof Way and Others," Journal of Economic Perspectives, vol. 17, no.4, Fall: 145-166.

Treasury (United Kingdom), (1999). "The New Monetary Policy Framework," London, H.M. Treasury. 
Ueda, Kazuo (1999). "Why the Bank of Japan Won't Target Inflation”, Wall Street Journal, March 6.

Vogel, Ezra F. (1979). Japan As No. 1: Lessons for America, Cambridge, MA: Harvard University Press, 1979. 


\section{Appendix: Inflation Targeting as discussed in Monetary Policy Meetings (MPM), A Chronological Review ${ }^{42}$}

Inflation targeting was first discussed by the Board on 16 July 1998. One member "remarked that inflation targeting was worth considering as it could work on people's expectation. ... in an extremely severe economic situation in which an optimal monetary policy was to realize negative real interest rates, targeting inflation at a moderate rate, for example at 1.0-1.5 percent, would be worth considering as an effective way of dispelling deflation". The need for positive inflation expectations to overcome the problem of the zero-bound of the nominal interest rate was correctly recognized, and the Board member noted that inflation targeting was a means to achieve positive inflation expectations. ${ }^{43}$ According to the minutes, no substantial discussion followed.

The next discussion of inflation targeting did not occur for four months. The minutes of 27 November 1998 recorded discussion of the pros and cons of introducing inflation targeting and also some technical questions. According to the minutes, one member proposed that "the Bank would encourage the uncollateralized overnight call rate to move on average around 0.15 percent, aiming at raising the annual average rate of increase in the consumer price index (all items) to zero in the medium term". Other members commented on this proposal. One member asked three technical points: "(1) How could a situation that is neither inflationary nor deflationary be described over price indicators, 'rate of increase at zero' or 'an increase by a small margin'? (2) What indicators should be used in measuring prices, the consumer price index (all items) as suggested in the proposal or other alternative price indicators? (3) How long the target period could be to achieve certain results"? These are essential questions, and if they had been seriously discussed, the introduction of inflation targeting might have been feasible as early as end-1998. However, there seemed to be some objections and scepticism towards inflation targeting in this meeting. One member doubted that announcing an inflation target "could have effects on the activities of people expecting deflation". Another member questioned the need for an announcement altogether, since it was known that the Bank was pursuing price stability. ${ }^{44}$

42 The minutes record a detailed summary of discussion of the MPM, and are made public after they are approved in the MPM meeting of one to two months later. Names of discussants are not disclosed, except for those who propose a motion for voting decision and voting records.

Transcripts with names will be disclosed in the distant future.

43 "Another member remarked that inflation targeting was worth considering as it could work on people's expectations, an opinion that the member had been expressing publicly. ... The member had advocated that in an extremely severe economic situation in which an optimal monetary policy was to realize negative real interest rates, targeting inflation at a moderate rate, for example at 1.0-1.5 percent, would be worth considering as an effective way of dispelling deflation concerns" (Minutes of the Board on July 16, 1998).

44 "Some members questioned the consistency between setting a price target and reducing the uncollateralized overnight call rate by 0.1 percent. In addition, one of the above members doubted that announcing such a target could have effects on the activities of people expecting deflation. (Para.) Another member expressed an opinion that the Bank did not need to indicate a specific target figure because it had already been widely known that the Bank has responsibility for stabilizing prices, that is to avoid inflation and deflation, as stipulated in Article 2 of the Bank of Japan Law. (Para.) Another member expressed a view that, in implementing monetary policy, it was natural that a central bank has a will to avoid genuine deflation. The member was, however, of the opinion that it was not appropriate to declare such a will in the form of inflation targeting, 
In 1999, inflation targeting was discussed fairly regularly. Inflation target(ing), or the target (range) of inflation rate, was mentioned at least once from February 1999 to February 2000. In several of the meetings, a substantial discussion took place (evidenced by comments of more than two persons, and more than five counts of "inflation target" recorded in the minutes). In particular, discussion on 28 June 1999, 27 October 1999, and 20 February 2000 seems to have been very interesting.

At the 28 June 1999 meeting, "One of the members, who considered that deflationary concern persisted, advocated further monetary easing through inflation targeting and expansion of the monetary base". He gave six reasons for this proposal, including its effects on expected inflation. The rise in expected inflation greater than the nominal long-term interest rate would lower the real long-term interest rate. Several members commented on this assertion and proposal. Some were sceptical of the "argument that a rise in nominal interest rates would be acceptable as long as real interest rates declined, saying that economic activities were affected by both nominal and real interest rates. "The criticism of inflation targeting based on a scare of rising long-term interest rate was debated without a firm conclusion.

In the MPM of 27 October 1999, the minutes recorded a lengthy summary of discussions. This was probably the first Board discussion that contained serious debates between advocates and sceptics of inflation targeting. ${ }^{45}$ There were two or more advocates of inflation targeting and others who were sceptical. Advocates argued that "inflation targeting had the merit that it enabled the Bank to indicate a medium- to long-term commitment". Sceptics argued that "it was too simple to think that setting a numerical target would increase the transparency of monetary policy, and it was necessary to discuss the pros and cons as well as the feasibility of inflation targeting giving due consideration to its basic nature". One member compared "a medium-term inflation target", which allows short-term flexibility, and a rule-like inflation targeting policy, "where every possible measure was employed to create a certain level of inflation", and preferred the former, "although it involved technical difficulties". These comments suggest a deeper understanding of the different types of inflation targeting, the reasons why such a policy was advocated, and the cautions involved in setting a target.

The MPM of 10 February 2000 provided another instance of detailed discussion on inflation targeting. The following was recorded as the "consensus" of the Board on inflation targeting: "First, they were against inflation targeting that aimed at creating a certain level of inflation - a reflation policy - and had no intention of adopting such a policy. And second, inflation targeting that aimed at making monetary policy more transparent and expressing a strong commitment to price stability was worth considering, although it had some technical difficulties". Many members "shared the opinion that, in deliberating inflation targeting in the latter sense, it was necessary to go over in further depth the various points of consideration that had been revealed at previous MPMs. Also, it was important to examine not only the pros and cons of inflation targeting but also various issues related to enhancing the transparency of monetary policy - for example, what was meant by price stability and whether to disclose the Bank's forecasts of prices and the economy".

and in addition, it was difficult to include the declaration of the will in the directive on money market operations, and the will should rather be expressed in some other forms and styles" (Minutes of the Board, November 27, 1998).

45 Coincidentally, this was the first MPM after Ito's (1999) Financial Times article. 
This almost sounds as if the Board would examine technical issues in preparation for the introduction of inflation targeting to enhance transparency and commitment. However, there was a cautious remark by one member: "First, it could pave the way for a policy that aimed at creating a certain level of inflation as hopes were strong that inflation would lighten the burden of debts. And second, the degree of the upward bias of price indexes changed as structural reform progressed. The member continued that it was preferable to enhance transparency by disclosing economic forecasts and thereby realize constructive dialogue with financial markets". What happened in the subsequent months was that this cautious person's view carried the meeting. From the spring to the summer of 2000, many members of the Board were busy debating whether and when the ZIRP policy would be ended, and no discussion on inflation targeting took place. The Board also carried out, or asked the staff to prepare, a study "on price stability", which would be made public in October 2000. At this time, individual Board members would also issue personal forecasts for prices and economic activity. So it seems that a series of debates from mid-1999 to February 2000 resulted in more basic study, which would take more than six months, and alternative ways of achieving "transparency". Effectively, the Board rejected the adoption of inflation targeting in 1999 and early 2000.

On 9 March 2000, the Board decided to conduct a comprehensive review of the price stability. The Chairman (Governor) proposed that the staff conduct the study on price stability as follows:

(1) The Bank's staff would study the following issues taking account of the points discussed at MPMs: (a) the Bank's basic thinking regarding price stability; (b) issues regarding price indices; (c) the evaluation of recent price developments in Japan; and (d) issues related to the numerical quantification of price stability (including setting a target and projecting the movement of a specific numerical indicator).

(2) The Board would discuss price stability on the basis of the staff's report, and issue a comprehensive report on its thinking on price stability.

(3) During this process, the Bank could release information compiled by the staff that was appropriate for disclosure.

(4) The Bank would issue a report by around the end of summer 2000.

It was advantageous that a comprehensive study would be conducted, but in retrospect, this action put off, or at least put aside, any further discussions of inflation targeting, until the study's completion. In the meantime, in the meeting of 11 August 2000, the ZIRP was ended on the majority's judgement that deflationary concern was dispelled. In fact, at that point, "deflation" was not defined by the Board, since it was under study. Although it was planned to be released by "the end of summer 2000", the study was not issued until October 2000.

On 13 October 2000, the long-awaited document "On Price Stability" was released, along with the "Release of Outlook and Risk Assessment of the Economy and Prices". Both documents were discussed by the Board. The discussion reveals the thinking of Board members at the time quite well. Below are excerpts from the minutes and my comments on them. 
[D]iscussions centered on the issue of expressing price stability by a numerical value. A few members expressed the view that the optimal rate of increase in price indexes over the medium and long term was small but positive considering issues such as the upward bias of price indexes and the zero constraint on nominal interest rates.

This view on "optimal rate of increase in price indexes" expressed by "the few members" seems quite appropriate and completely non-controversial from the view of mainstream monetary economics. What is surprising is the discussion that follows.

However, many members including those above agreed with the conclusion of the report that it was not appropriate to define price stability by numerical values at this point for the following reasons. First, supply-side factors such as technological innovation were exerting downward pressure on prices at present. And second, the available orthodox monetary policy measures were limited. At the same time, these members shared the view that the Bank should continue to explore whether price stability could be expressed by numerical values, taking account of actual changes in the market and the economy.

This paragraph summarizes why the Bank of Japan did not adopt inflation targeting in 2000. First, it was thought that if supply-side factors were affecting price levels, inflation targeting was inappropriate. However, as was discussed earlier in this paper, demand, not supply, factors were dominant, since output was sluggish in Japan, but not in the United States. Also, supply side factors mostly affect relative prices, and average prices are more affected by macroeconomic factors and policies. Second, the Board recognized that the room for maneuver with conventional policy measures, that is, the interest rate, was limited. At this time, the Bank had just raised the interest rate to 0.25 per cent, and the majority of the Board was not considering lowering it back to zero.

Board members asked for a number of further issues to be studied: (1) the relationship between price stability and financial system stability; (2) whether it would be inappropriate to use numerical values to express a price stability objective, as long as downward pressure on prices from the supply side remained; (3) ways to improve data on the supply side that were essential for assessing prices; and (4) ways that countries that had adopted inflation targeting would deal with issues related to technological innovation, which made compilation of reliable price statistics more difficult, and asset prices, which were becoming increasingly important for the conduct of monetary policy.

These issues reveal that the majority of Board members thought either that setting a numerical target was a bad idea, when supply side factors are having a large impact, or that more research was needed on the issue. The following paragraph seems to give a summary view of the majority of the Board:

[A]nother member said that it would be difficult to define price stability in terms of numerical values in view of structural changes that Japan was undergoing, bias in price indexes, and Japan's economic situation which was subject to strong influence from external developments. Therefore, the member thought that the issue should be studied further and would, at this 
point in time, prefer to give only a qualitative or conceptual definition of price stability. The member further commented as follows. The discussions on the issue of quantifying price stability had been initiated in response to public criticism that the goal of monetary policy was unclear. Therefore, the discussion started from the very fundamental question of the significance of price stability, but some issues required further study. In that sense, the member would like to emphasize that the conclusion was not fully satisfactory.

In contrast, one member in favor of inflation targeting gave the case for immediate adoption:

One member, while supporting the Bank's plan to make public its thinking on price stability, disagreed with the contents of the report as the member believed that the Bank should immediately set a numerical target for the inflation rate. The member expressed the following opinions. First, without a numerical target, the Bank would not be able to assess its performance and would not be accountable to the public as a central bank. Second, it was natural that an inflation target should be adjusted in line with structural changes and this would make the adoption of an inflation target viable. And third, the European Central Bank (ECB) had defined price stability as year-onyear price increases of below 2 percent, and some central banks in industrialized countries, such the United Kingdom and New Zealand, had adopted inflation targeting. In view of this, the report should explain convincingly and in depth why Japan did not have a numerical target for prices.

After the discussion on the document of 13 October 2000, there was no significant discussion on inflation targeting or price indices until 19 March 2001, when the Board decided to the change the monetary policy instrument from the interest rate to the current account at the Bank of Japan, effectively restoring ZIRP.

The minutes of the 19 March 2001 meeting contain interesting discussions on adopting a condition for continuing ZIRP. The Board members agreed to ease monetary policy, given the deteriorating economic conditions. Members agreed that "(1) it was necessary to make a strong commitment in terms of policy duration in order to ensure the 'commitment effect', and (2) it was desirable to make the commitment clearer than 'until deflationary concern was dispelled', the phrase the Bank had used under the zero interest rate policy". In a sense, they admitted that this time the Bank had to explain ZIRP better than it had when it was previously used (from February 1999 to August 2000). Thus, a clearer expression than "until deflationary concern was dispelled" was sought. The change in the policy instrument and the exit conditions were decided as follows:

1. The Bank will change its main operating target for money market operations to the outstanding balance of the current accounts at the Bank of Japan.

2. The Bank will continue the new framework for money market operations prescribed in 1. until the CPI (excluding perishables, on a nationwide basis) registers stably a zero per cent or an increase year on year.

It is remarkable that the Board agreed on: (1) the particular price index, CPI excluding fresh food, that it was going to focus on as a condition of monetary policy; and (2), 
the numerical number, zero. The zero was chosen because the Board members "were in agreement that a situation that was neither inflationary nor deflationary was desirable, and thus, it was appropriate to make a commitment to continue the policy until the rate of increase in the CPI recovered to zero percent". One member, citing a study that suggested the upward bias in the CPI in Japan was 0.9 per cent, insisted that a higher number was chosen, but did not prevail. Instead, "[o]ne member added that, although the Policy Board should further discuss the desirable rate of increase in prices, it would be appropriate to use a phrase such as "stably a zero percent or an increase year on year" and imply that it would conduct policy "aiming at a small but positive inflation rate". In the end, the vote was taken to endorse a new policy: "(1) change the main operating target for money market operations to the outstanding balance of the current accounts at the Bank of Japan; and (2), make a commitment to continue this new framework until the CPI registered stably a year-on-year increase of zero percent or more".

This meeting finally put to end the discussion of what was the appropriate price index. The discussion had persisted for almost three years. Even in the major document "On Price Stability", which was released just six months earlier, the question was not settled. But, suddenly, in this MPM, the question of appropriate price index was resolved.

This MPM is also remarkable in the sense that the Board endorsed what was considered to be quantitative easing that had long been resisted. Specifically, the Board voted in favor ( 8 in favor, 1 against): "(3) change the main operating target for money market operations to the outstanding balance of the current accounts at the Bank of Japan, (4) make a commitment to continue this new framework until the CPI registered stably a year-on-year increase of zero percent or more, (5) increase the amount of the Bank's outright purchases of government bonds when it was considered necessary in order to provide liquidity smoothly, (6) establish a clear ceiling for the Bank's government bond holdings, set at the outstanding amount of banknotes issued, and (7) increase the outstanding balance of current accounts at the Bank to around 5 trillion yen for the time being".

What was curious about this MPM discussion is that the Board members denied any link of this new commitment strategy to inflation targeting.

Many members agreed that such a commitment differed from inflation targeting in that under the latter a desirable inflation rate from a medium- to long-term perspective was set as a target and monetary policy was changed when the inflation rate was expected to deviate from the target.

From the viewpoint of inflation targeting advocates, these measures, including deciding on the price index to measure inflation, mentioning the number zero, and taking actions on quantitative easing, were more than a half step towards fully-fledged inflation targeting. It is quite puzzling to the advocates of inflation targeting why the Board members still had to deny the resemblance of the new policy to inflation targeting. If one wants "commitment", inflation targeting is the better way. Perhaps "target" was a word that was disliked by the Board members, as it would make the Board accountable for the consequences of its actions.

At the 19 March 2002 meeting, an advocate of inflation targeting made a proposal that the numerical target should be made in consultation with the government: "[O]ne member said that it was not appropriate to introduce a numerical target with a specific time frame without having any concrete means to achieve the 
target, but it would be meaningful if the Bank shared a numerical target for prices with the Government in some way as a policy framework. In response to this, one member said that in setting a numerical target with the Government, the Government's policy commitment in achieving the target would be another important factor, but there could be a contradiction in the current deflationary situation between implementing fiscal consolidation and setting an inflation target".

From the fall of 2002 to the beginning of 2003, an interest in inflation targeting re-emerged. The Board had two intensive discussions, on 10 October 2002, and 21 January 2003. During this time, discussions on inflation targeting were also gathering pace outside the Bank of Japan, as the end of the terms of Governor Hayami and the two Deputy Governors were approaching, and interest was raised in whom the government would appoint as replacements. The Bank felt defensive at first, but subsequently presented arguments to convince the public about the correctness of the policy. They emphasized the importance of explaining what they had been doing in one of the MPMs. ${ }^{46}$

In the MPM of 10 October 2002, several negative opinions on adopting inflation targeting were mentioned. Inflation targeting was characterized by some members as inappropriate because it has "negative effects on the economy and the financial system, such as damage to the credibility of economic policy and to financial markets, would exceed the positive effects". The implication seems to be that inflation helps debtors. Another member commented that given that quantitative easing did not stop prices declining, and as more negative shocks were expected from an accelerated resolution of the problems of non-performing loans, inflation targeting was not appropriate due to a lack of instruments to achieve it.

Members who commented on inflation targeting expressed the view that if inflation targeting were to be adopted in the current economic situation, the mechanism to achieve the target would rely mostly on an upward shift in inflationary expectations, unless public expenditures were substantially increased. These members then said that it was theoretically not possible to shift inflationary expectations upward unless there were sufficient and credible policy tools and transmission mechanisms to achieve the target, and that setting a target in the absence of such tools and mechanisms would impair public confidence in economic policy as a whole.

This summarises the negative opinion at the time quite well. Concern about the implications for the long-term bond rate was also expressed: "if inflationary expectations were to shift upward, it was the bond markets that would be most likely to be affected". ${ }^{47}$ One member countered that "effects of a rise in long-term interest

46 In connection with the critics' call for taking more drastic policy, the Board member remarked that "it was vital to explain the risks and the possible side effects of individual policy tools as concretely as possible, in order to gain greater public understanding of the Bank's conduct of monetary policy" (January 21, 2003).

47 "Based on the above discussion, these members said that if long-term interest rates rose before economic activity was sufficiently stimulated, this was likely to cause the economy to make a hard landing, the opposite result to an easing of the pain arising from NPL reduction. This was because a rise in long-term interest rates would substantially increase the interest burden on the Government and firms and would negatively affect the financial position of banks since they held a huge amount of JGBs" (October 10, 2002). 
rates on banks' balance sheets, ... might be smaller than expected, ... because banks had been controlling risks". 48

It is interesting that some members suggested that the Bank was essentially running an inflation targeting policy without saying so.

“the Bank's current monetary easing was already aimed at incorporating the advantages of inflation targeting, given the monetary policy measures the Bank could adopt in the current situation. ... One of these members said that the Bank had already adopted inflation targeting policy in a broad sense, in that it made a commitment to continue the quantitative easing measure until the consumer price index registered stably zero percent or an increase year on year. On this basis, this member pointed out that the difference between the Bank's current easing policy and inflation targeting in a strict sense was mainly whether the specific period within which the target was to be achieved was indicated. This member added that the latter policy would inevitably require extreme measures that would have serious risks or adverse effects".

Given that in the 19 March 2001 meeting, a sharp dissociation of the new policy from inflation targeting had been recorded, this kind of assessment is very interesting. It is not clear whether more Board members became favorable to inflation targeting or Board members wanted to counter the call for inflation targeting by saying that it had already been adopted.

The MPM of 21 January 2003 turned out to be the last MPM that discussed inflation targeting at length, and probably the longest discussion to date under the regime of Governor Hayami. Again, the dominant view rejected the adoption of inflation targeting. First, "[o]ne member pointed out that inflation targeting had never been adopted for the purpose of overcoming deflation by any central bank overseas, including those in New Zealand and Sweden". Second, without having conventional monetary easing measures, setting an inflation target with a specific time limit is different from situations of other inflation targeting countries. They were implying that there are no measures to achieve inflation target: "First, there was a large output gap and a financial system problem. Second, short-term interest rates were at the zero lower bound. Third, fiscal consolidation and structural reform were in progress. And fourth, global downward pressure on prices of goods was substantial".

Some recognized that the government has more tools than the Bank of Japan to stimulate the economy, namely fiscal spending and foreign currency intervention. ${ }^{49}$

48 Another member said that the Bank's current monetary easing measures along with the commitment effect in terms of policy duration had reduced interest rates with relatively long maturity to the lowest possible level, which in turn supported the Government's funding. In this sense, the current policy was desirable in terms of harmonization with the Government's policy. This member said that it was difficult to understand why some Government officials advocated inflation targeting in the current situation despite the possibility that it would cause a rise in longterm interest rates and would increase the Government's interest payments. This member expressed a desire to hear the Government participants' opinion, if possible (October 10, 2002). 49 Some members remarked that, to make the inflation rate positive within a relatively short period, substantially expanding fiscal spending or conducting an active foreign exchange rate policy would have to be considered as policy options. These members said that, if an inflation target were set by the Bank alone, it would not be credible, since fiscal and foreign exchange policy were under the control not of the Bank but the Ministry of Finance. These members also 
Some Board members were probably unaware that the Ministry of Finance was about to launch an unprecedented scale of foreign exchange interventions starting this month (January 2003) to March 2004.

What is somewhat surprising is an expression again that the Bank was already practicing de facto inflation targeting, just like the opinions expressed in the 10 October meeting.

Some members noted that the Bank's commitment to continue the current monetary easing framework until the inflation rate became stably zero or more had virtually already factored in most of the effects that inflation targeting purported to achieve. This was because the commitment using the actual figure of the CPI, not a forecast figure, reflected in fact the Bank's intention to achieve a small positive inflation rate, taking into account the time-lag.

They viewed calls for the adoption of inflation targeting as based on a misunderstanding of "side effects" of policies that are required to achieve an inflation target, and these misunderstandings had been corrected.

One member raised, as a thought experiment, the question of how the Bank should approach the issue of adopting inflation targeting, if the Government were to concede total control over both fiscal and foreign exchange policy to the Bank and if the Government were to cover all losses arising from the Bank's purchases of risky assets. This member said that this exercise would be useful in considering how the Bank should respond to calls to adopt inflation targeting, particularly from academics overseas: "[T]he view that inflationary expectations would be shifted upward merely by a central bank's announcement of inflation targeting was becoming a minority opinion overseas. Moreover, the view that the remaining measures that could be employed by the Bank alone were ones whose effects were uncertain seemed to have become the majority view overseas. These members pointed out that the risks and side effects of individual policy tools had not been sufficiently understood, and this lack of understanding was behind the persisting view that the Bank should try adopting any policy tool, if the possible side effects could be considered small, even though its effectiveness might be uncertain".

Moreover, the suggestion by critics of the Bank's policy of purchasing risky assets would be harmful due to side effects: "In relation to this, one member said that there was an extreme view that the Bank should purchase not only JGBs and foreign bonds but also risky assets that were securitized such as stocks and real estate without limit until prices rose. However, if the Bank actually implemented such a policy, it would be likely to cause many side effects, such as a loss of fiscal discipline, a deterioration of the central bank's assets, and a rise in long-term interest rates, and would therefore negatively impact the economy before the inflation rate rose".

Some Board members criticized inflation targeting because it would destabilize the market: "One member noted that inflation targeting was basically aimed at stabilizing people's expectations. However, the mechanism of an upward shift in inflationary expectations currently envisioned by advocates of inflation

contended that, if Japan were to prioritize realizing a positive inflation rate with a certain time limit, it would be essential for the Government to give a concrete outline of how it would conduct fiscal and foreign exchange policy to achieve it (January 21, 2003). 
targeting was highly likely to destabilize people's expectations, and this could in turn destabilize long-term interest rates and the economy. This was because, as most people still expected that it would take time to overcome deflation, some would start to anticipate that to achieve the target the authorities would employ extreme means that could damage the public's confidence in them". This argument is difficult to understand, because if inflation targeting is credible, it would certainly stabilize expectations. To endorse people's expectations that it would take a long time to overcome deflation - to not rock the boat - sounds like a strategy not to fight deflation.

Then, without inflation targeting, how would deflation be overcome? Many Board members remarked that deflation would be overcome when the economy got back on the path of sustainable growth, but how to achieve growth was not particularly well answered. ${ }^{50}$ They basically reaffirmed that there is little that the monetary policy can do.

50 "One member emphasized that the measures to overcome deflation were not ones designed to create inflation, but ones that would realize sound economic growth.... overcoming deflation could only come into prospect when the economy realized sustainable growth. The member continued that the authorities should present credible policies to deal with the fundamental cause of the price falls, namely the lack of demand and the stagnation of the economy. ... two factors were causing the decline in economic growth in Japan, namely, the weakness in aggregate demand and the delay in overcoming structural problems of the economy. ... fiscal policy could still have a great impact in revitalizing the Japanese economy, and the efficiency of fiscal spending would significantly affect the direction of the economy". 
Figure 1: Inflation Rates in Japan: CPI and GDP deflators

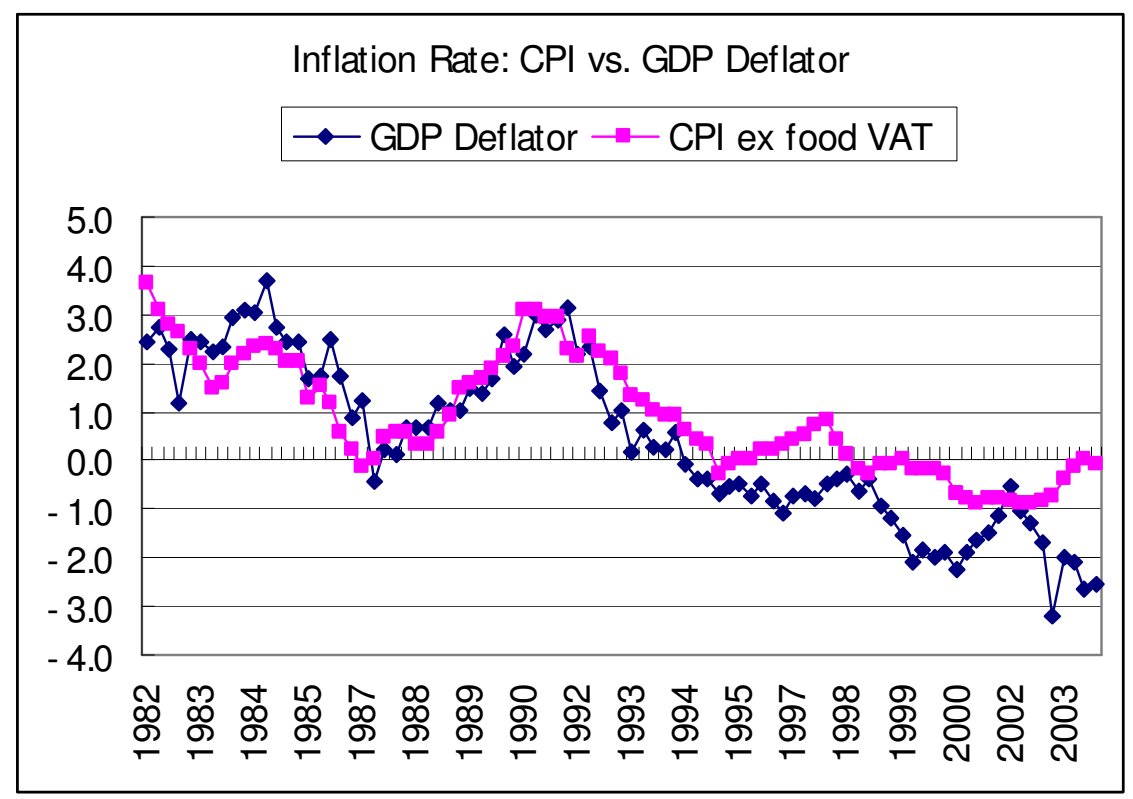

Notes:

The following adjustments are done to the original series in order to remove the effects of value-added tax (consumption tax) rate increases. The tax was introduced, with $3 \%$ rate on all goods and services, in April 1989, with abolishment of many excise taxes. Some very small establishments were exempted from charging the consumption tax. The tax rate was hiked from 3\% to 5\% in April 1997.

Adjustments were as follows.

For CPI I 1989.2-I990.I, the adjustment of minus 1.3 percent is deducted

For GDP deflator, 1989.2-1990.l, the adjustment of 1.4 percent is deducted

For 1997:II to $1998: I_{7} 1.5 \%$ is deducted from CPI inflation to offset consumption tax increases

For 1997:II to 1998:I $1.3 \%$ is deducted from GDP inflation to offset consumption tax increase

[FILE: CPIChg-GDPDefChg ] 
Figure 2: Inflation and Growth rates, 1975-2004; CPI vs growth, and GDP deflator vs. growth
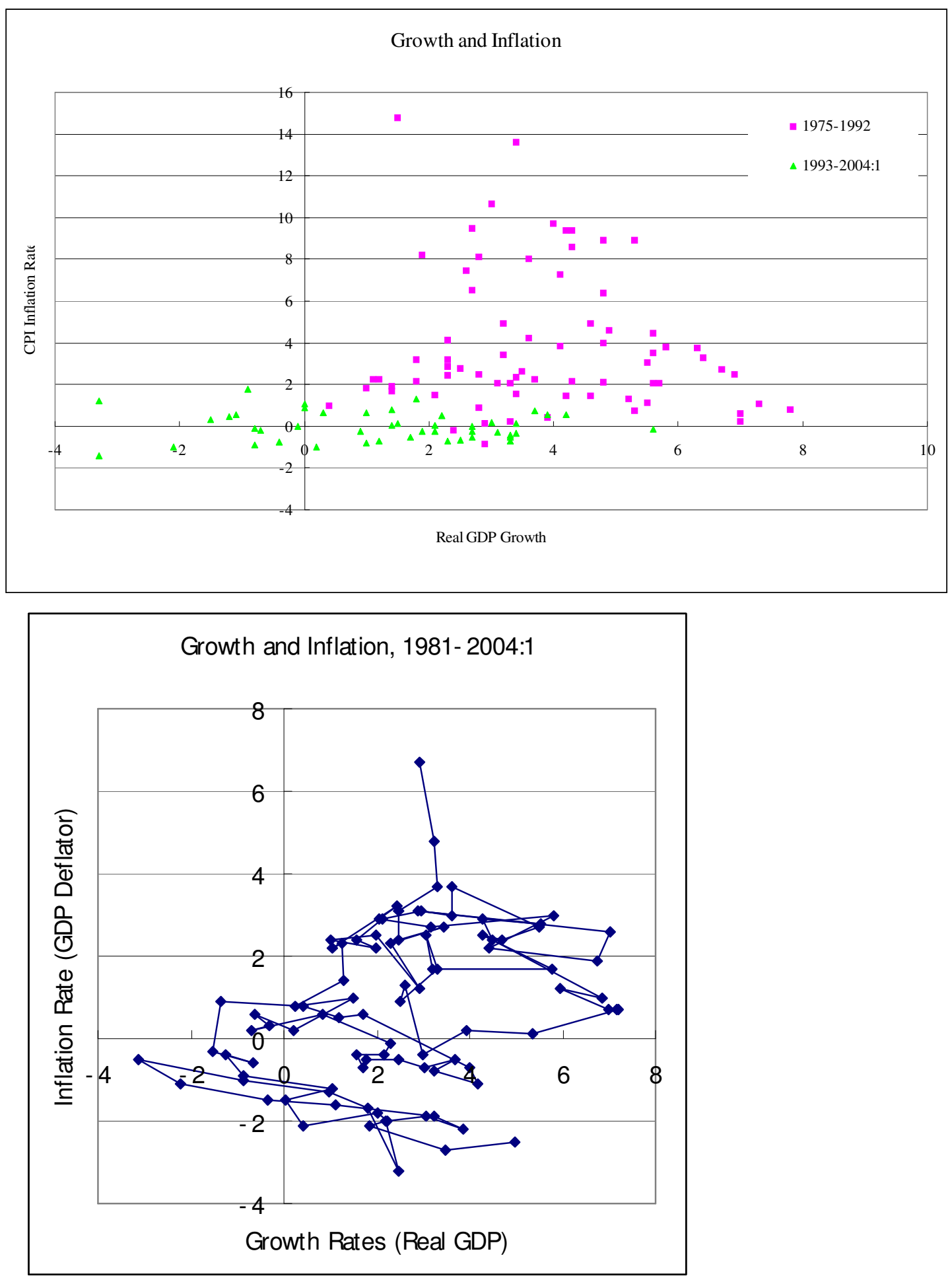
Figure 3: Phillips Curve, 1975-2004

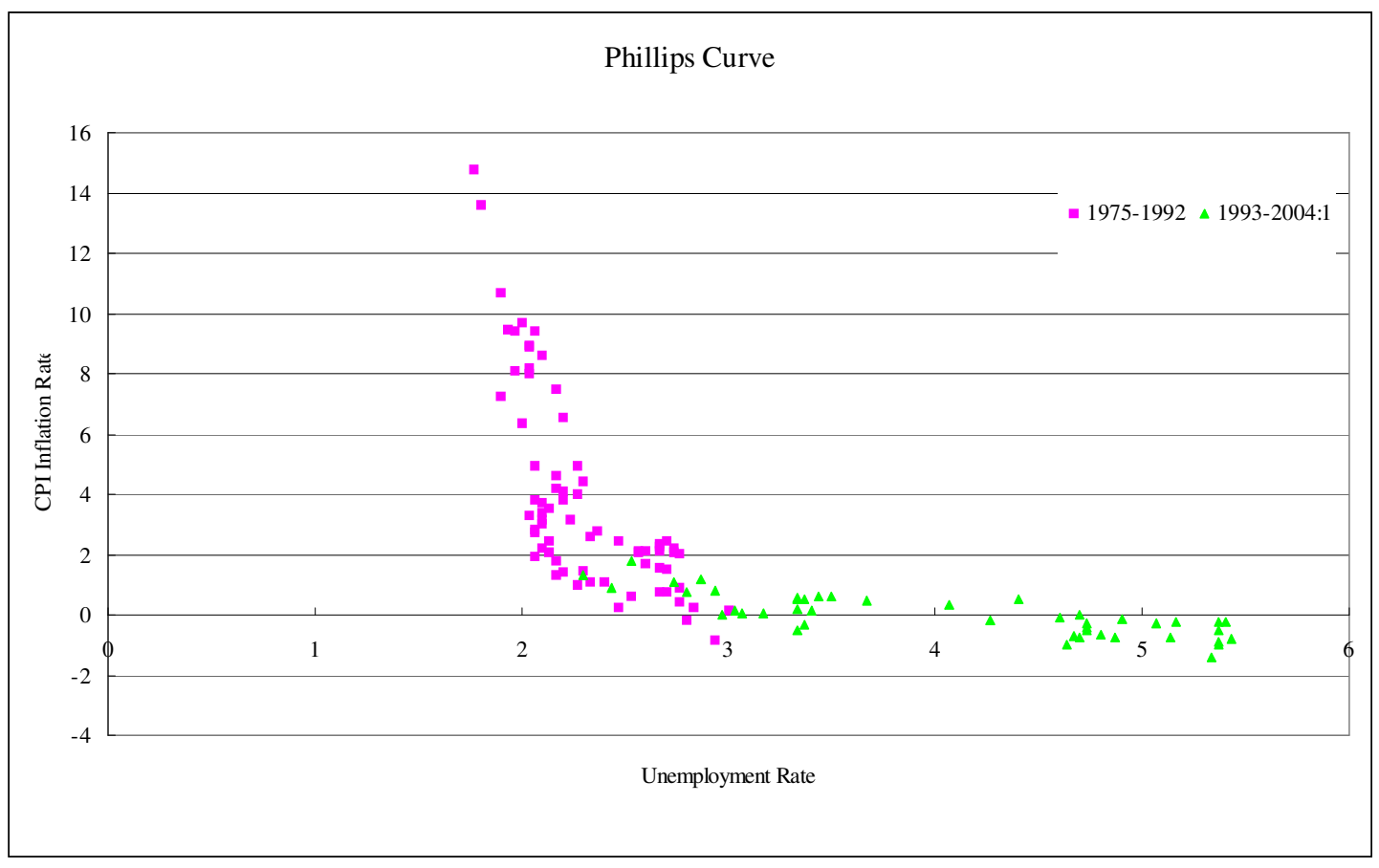

Notes: Inflation rates are calculated as the change in the CPI from the same quarter of the year t-1, adjusted for VAT rate changes, and the unemployment is all ages, national average. 
Figure 4. Quantitative Easing

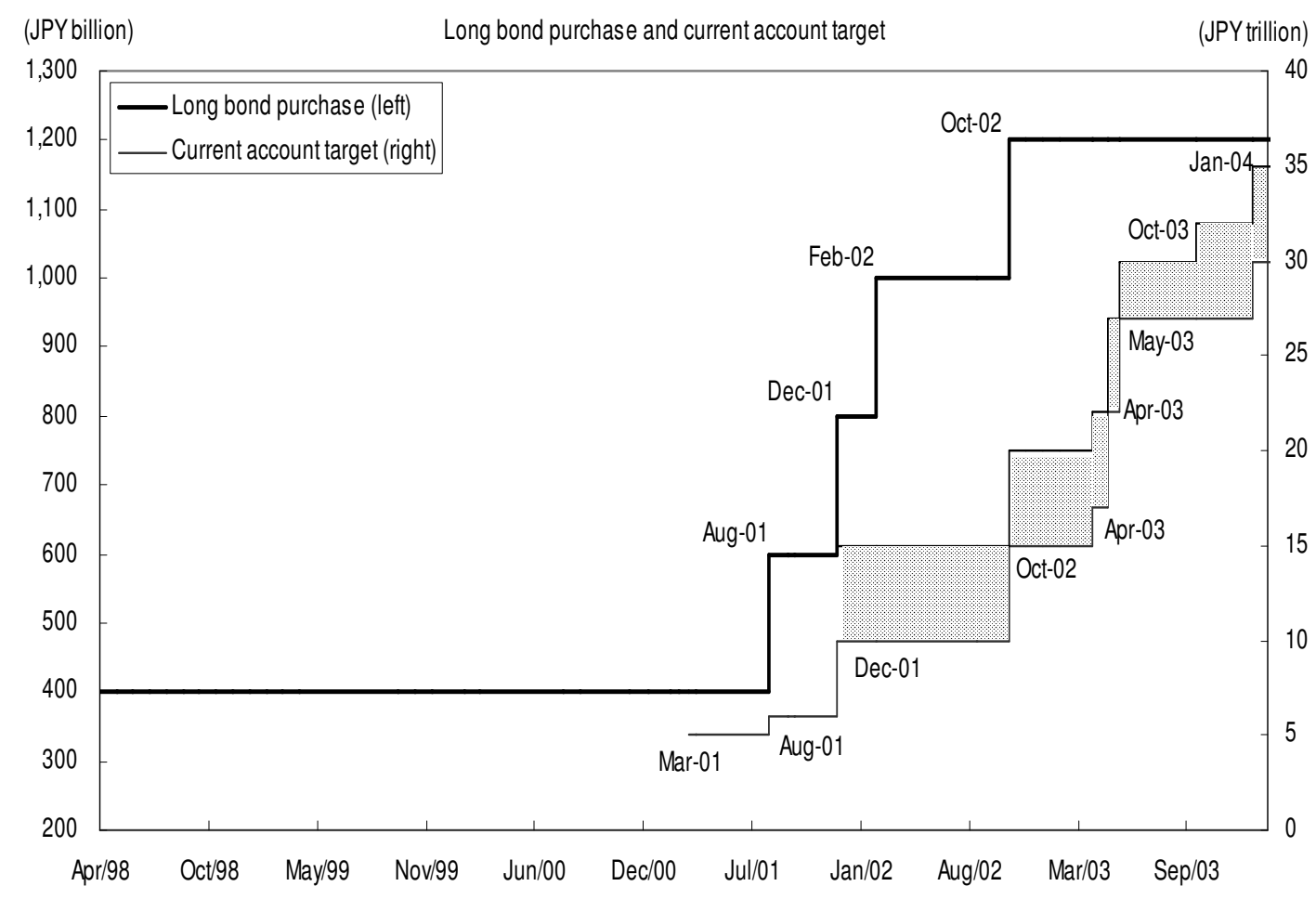


Figure 5

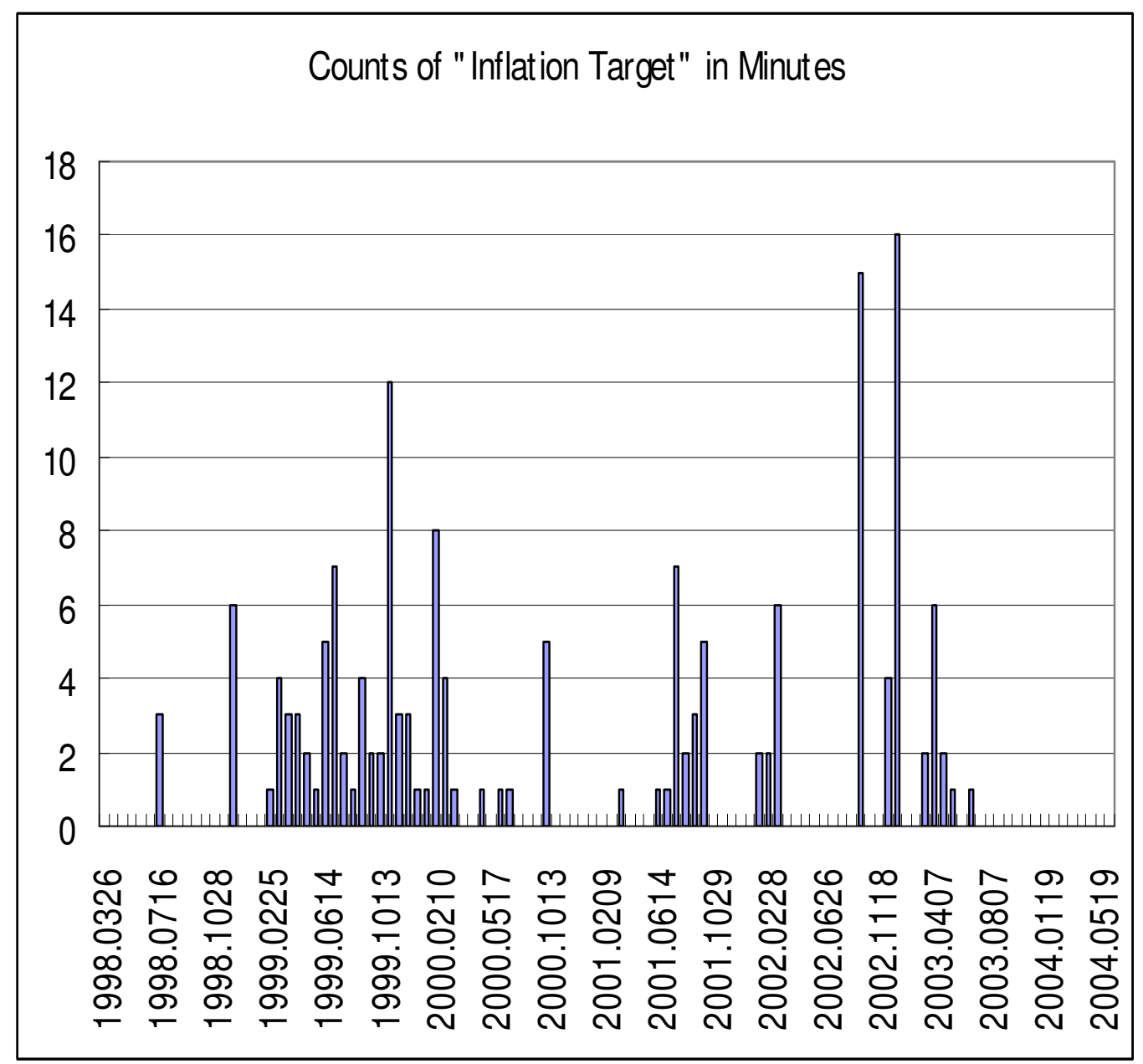

Source: All the disclosed "Minutes" of the Bank of Japan. Counts by the Author.

Notes: In each Minutes, the "Counts" is defined by a total number of occurrence of the following words: "Inflation targeting", "inflation (rate) target", "targeting inflation", "the target range of the inflation rate", "target for the inflation rate", "numerical target for (the future) inflation (rate)", "special target for the inflation rate", "a medium-term target for the inflation rate", "a medium-term inflation rate targe,", "the target for the monetary base and the inflation target", "the target inflation (rate)", "a target with a clearer time horizon that the year-on-year inflation", and "neither a target nor a reference rate of inflation." 